Turyzm 2020, 30/2

\author{
Wiesław Alejziak \\ https://orcid.org/0000-0002-0604-7577 \\ Bartosz Szczechowicz \\ https://orcid.org/0000-0002-9019-9396 \\ Akademia Wychowania Fizycznego w Krakowie \\ Wydział Turystyki i Rekreacji \\ Instytut Przedsiębiorczości i Zarządzania \\ wieslaw.alejziak@awf.krakow.pl, bartosz.szczechowicz@awf.krakow.pl
}

\title{
EKSPERCKIE PROGNOZY SKUTKÓW TRENDÓW TURYSTYCZNYCH W ŚWIETLE OCENY EX POST STUDENTÓW POLSKICH UCZELNI
}

\begin{abstract}
Abstrakt: Celem artykułu - rozwiniętym w kilku pytaniach badawczych - jest ustalenie, czy student turystycznych kierunków kształcenia może być skuteczny w rozpoznawaniu trendów obecnych w sferze turystyki. Dla realizacji celu: 1) zidentyfikowano 10 trendów (wraz z ich 47 skutkami) dotyczących przemian zachodzących w ostatnich latach w sferze turystyki - przyjętych przez ekspertów European Travel Commission oraz European Tourism Action Group; 2) trendy te oraz zidentyfikowane przez ekspertów skutki poddano krytycznej ocenie studentów, połączonej z daną im możliwością uzupełnienia listy eksperckiej o inne (własne) skut$\mathrm{ki}$; 3) porównano oceny i wskazania studentów z aktualnymi trendami, identyfikowanymi w innych badaniach i raportach. Badania zrealizowano wśród studentów kierunku turystyka i rekreacja w Akademii Wychowania Fizycznego w Krakowie oraz w Szkole Głównej Turystyki i Hotelarstwa Vistula w Warszawie w latach akademickich 2017/2018 i 2018/2019 na próbie 95 osób. Zaprezentowano też wyniki badań, którymi objęto w sumie 113 studentów, 17 wykładowców oraz 76 pracowników biur podróży, przeprowadzonych wcześniej (ale nigdzie nieopublikowanych) w dwóch innych ośrodkach akademickich (Rzeszów, Kielce). W sumie - w ramach wszystkich opisanych w pracy badań - zebrano opinie od 301 osób. W rezultacie ustalono, że studenci jako zbiorowość są wystarczająco dobrymi obserwatorami zmian zachodzących na rynku turystycznym, aby - wykorzystując wiedzę uzyskaną w trakcie studiów oraz charakterystyczną dla tej grupy kreatywność i wyobraźnię, a także znając problematykę prognozowania i metod scenariuszowych - celnie uzupełniać sugestie specjalistów. To z kolei prowadzi do wniosku, że studenci mogą być wartościowymi uczestnikami badań mających charakter burzy mózgów.
\end{abstract}

Słowa kluczowe: turystyka, rynek turystyczny, trendy, tendencje, foresight, metoda ekspercka, student.

\section{WSTĘP}

W świetle obecnego stanu wiedzy wynikające $\mathrm{z}$ badań nad turystyką twierdzenie, że jest ona zjawiskiem niezwykle złożonym, w którym łączą się i przenikają rozmaite wymiary, czy też aspekty rzeczywistości, należy uznać za truizm. $Z$ uwagi na tę właśnie złożoność turystyka jest jednak nader wrażliwa na przemiany, jakie dokonują się $\mathrm{w}$ sferze potrzeb oraz pragnień jednostek (turystów), w strukturze demograficznej społeczeństw, w dostępności zasobów naturalnych i kulturowych, w warunkach technologicznych, w otoczeniu prawnym itd. W konsekwencji tego stanu rzeczy za zasadne, czy wręcz konieczne, trzeba uznać identyfikowanie wskazanych przemian poprzez uchwycenie różnych trendów (psychospołecznych, demograficznych, gospodarczych, technologicznych itd.) na rynku turystycznym. Autorzy artykułu rozumieją trendy jako ogólne prawidłowości w kształtowaniu się ocenianych zjawisk, abstrahując od charakteru rozpatrywanych zmiennych (ilościowe, jakościowe) oraz siły zmian, jakim podlegają. Ściślej rzecz ujmując, trendy uznaje się za „zjawiska krótko- lub długookresowe o zasięgu regionalnym lub globalnym, opisywane najczęściej w kategoriach ekonomicznych, socjologicznych lub psychologicznych (style życia określonych segmentów rynku i związane z nimi wzorce konsumpcji), wpływające na różne sektory biznesu" (Vejlgaard, 2008, cyt. za: Hajdas, Szabela-Pasierbińska, 2016, s. 233).

Świadomość aktualnych trendów jest ważna dla wielu podmiotów, także działających w sferze turystyki. Przede wszystkim jest istotna dla włodarzy regionów oraz państw, którzy powinni mieć racjonalne podstawy do kreowania i wdrażania założeń 
realizowanej polityki, włączając w to tworzenie prawa oraz oddziaływanie na otoczenie poprzez stymulowanie trendów korzystnych dla społeczeństwa, a ograniczanie tych, które nie są korzystne - a przynajmniej minimalizowanie ich negatywnych konsekwencji (Alejziak, Szczechowicz, 2019). Wiedza ta jest też potrzebna menedżerom przedsiębiorstw oraz innego typu organizacji, aby mogli oni podejmować skuteczne i efektywne decyzje dotyczące bieżącego funkcjonowania, a zwłaszcza kwestii strategicznych (np. inwestycji). Znajomość aktualnych trendów jest również istotna dla jednostek występujących w wielu różnych rolach społecznych i gospodarczych, by mogły one optymalnie gospodarować swoimi ograniczonymi zasobami (Coathup, 1999; van der Duim, Ren, Jóhannesson, 2013; Inskeep, 1991; Pearce, 2005; Wodejko, 2006; Yiannakis, Gibson, 1992).

W badaniach mających na celu identyfikację oraz analizy trendów wpływających na szeroko pojętą turystykę można wykorzystywać różnego rodzaju metody, służące - ogólnie rzecz ujmując - przewidywaniu zmian zachodzących w makrootoczeniu. Mogą to być zarówno metody tradycyjnie stosowane do przewidywania megatrendów, trendów, mikrotrendów oraz mód, jak i interdyscyplinarne studia nad przyszłościa, określane mianem foresight (Borodako, 2008; Hajdas, Szabela-Pasierbińska, 2016; zob. też EC, 2009)ํ․ Autorzy niniejszego artykułu, nie prezentując w nim istoty oraz specyfiki wszystkich tego typu metod, zaznaczają jedynie, że obecne wśród nich metody ilościowe bazują na modelach matematycznych, w ramach których wartości określonych zmiennych ekstrapolowane są w przyszłość, natomiast metody jakościowe opierają się na wiedzy eksperckiej. W związku z tym każdej z wyróżnionych grup metod można przyporządkować charakterystyczny (pożądany) profil osoby planującej i realizującej badania ukierunkowane na identyfikację trendów. W przypadku metod ilościowych osoba taka powinna się wyróżniać wiedzą z zakresu nauk ścisłych oraz umiejętnościami analitycznymi. W odniesieniu do metod jakościowych na pierwszy plan wysuwają się z kolei takie cechy, jak: wiedza, kreatywność, intuicja, doświadczenie, inwencja twórcza, pomysłowość, oryginalność (Hajdas, Szabela-Pasierbińska, 2016). W przypadku turystyki trzeba też mieć na uwadze, że w wielu sytuacjach oczekuje się od eksperta wiedzy kompleksowej, wieloaspektowej i interdyscyplinarnej, a nie wybiórczej.

Podstawa prognozowania zawsze jest poprawnie przeprowadzona diagnoza badanej rzeczywistości, czyli stwierdzenie aktualnego stanu badanych zjawisk, istniejących współzależności i sprzężeń zwrotnych oraz kierunków i siły oddziaływania czynników wewnętrznych i zewnętrznych, istniejących ograniczeń itd. Przy projekcji przyszłych zjawisk można skorzystać z wielu technik prognozowania, które różnią się między sobą przede wszystkim horyzontem czasowym oraz liczbą rozpatrywanych czynników.

Prognostyka umożliwia badanie przyszłości na wiele sposobów. Zasadniczo można je podzielić na trzy podstawowe grupy: metody ekstrapolacyjne, intuicyjne oraz interferencyjne (Grabiński, Wydymus, Zeliaś, 1993; Penc, 1997). Do pierwszej z tych kategorii zaliczane są metody, które opierają się na zaobserwowanych trendach rozwojowych danego zjawiska w przeszłości. Obserwacje te są punktem wyjścia do wnioskowania prognostycznego, przy którym wykorzystuje się różne modele ekonometryczne. $Z$ kolei metody intuicyjne nie są poparte ścisłymi obliczeniami, a podstawę całego procesu prognozowania stanowią twórcze możliwości ludzkiego umysłu, w tym zwłaszcza skojarzenia, swobodna wymiana poglądów oraz zgłaszanie pomysłów. Natomiast metody interferencyjne umożliwiają przewidywanie jednych zjawisk na podstawie innych, mimo że nie obserwuje się między nimi związków przyczynowo-skutkowych ${ }^{2}$.

Mając na uwadze te wyjaśnienia, za podstawowy cel niniejszego artykułu przyjęto udzielenie odpowiedzi na pytanie, czy skuteczną próbę identyfikowania trendów obecnych w sferze turystyki może podejmować jedynie doświadczony w tego typu działalności specjalista, czy też może to być osoba studiująca na kierunku związanym z turystyką. Za obraniem takiego celu przemawiają dwie okoliczności, które można uznać za założenia metodologiczne rozważań prowadzonych w niniejszym opracowaniu.

Po pierwsze studenci są z zasady osobami młodymi i otwartymi na wiedzę, a zarazem krytycznie oceniającymi otaczającą je rzeczywistość. Stanowi to dobrą podstawę do prowadzenia obserwacji i wydawania rzetelnego osądu o przemianach zachodzących w sferze turystyki, a jednocześnie daje nadzieję na rozumowanie nieschematyczne, pozwalające spojrzeć na otaczającą ludzi rzeczywistość w sposób odmienny od utartych, typowych dla ekspertów sposobów myślenia. Wiąże się z tym również fakt, że osoby realizujące obecnie, czyli w drugiej dekadzie XXI w., studia lub ich niedawni absolwenci to przedstawiciele tzw. pokolenia Z, charakteryzującego się m.in.: pewnością siebie, otwartościa, akceptacją różnorodności, świadomością znaczenia problemów globalnych dla życia jednostki i społeczeństw, skłonnością do ryzyka oraz umiejętnością szybkiego podejmowania decyzji (Chomątowska, Żarczyńska-Dobiesz, 2014). Są to również cechy, które mogą sprawić, że obecni studenci będą w stanie w sposób skuteczny i efektywny identyfikować trendy np. w sferze turystyki.

Po drugie studenci w ramach różnych zajęć zdobywają aktualną wiedzę z wielu dziedzin i dyscyplin nauki, co stanowi dobrą podstawę do analizowania sfery turystyki w całej jej złożoności i wieloaspektowości. 
O multidyscyplinarnym charakterze studiów z zakresu turystyki świadczą wyniki analizy profilów absolwentów oraz programów kształcenia realizowanych na różnego typu uczelniach (uniwersytetach, uniwersytetach ekonomicznych, technicznych, humanistycznych, rolniczych, akademiach wychowania fizycznego i in.) $)^{3}$, przygotowujących studentów do podjęcia pracy związanej z zaspokajaniem potrzeb i pragnień osób podróżujących ${ }^{4}$. Warto też odnotować, że wspomniana różnorodność może świadczyć o przewadze studentów nad ekspertami akademickimi, którzy koncentrują swoją uwagę na dokładnym poznaniu ściśle określonego obszaru rzeczywistości ${ }^{5}$.

Warto przy tej okazji wyjaśnić, że w uczelnianych programach oraz planach kształcenia nie zawsze uwzględnia się $\mathrm{w}$ pełni aktualny stan wiedzy i najnowsze wyniki badań naukowych. Wskazują na to studia przeprowadzone przez Gołembskiego (2016), który przyjrzał się programom nauczania przedmiotów oferowanych w ramach planów kształcenia na kierunkach turystycznych w 11 polskich uczelniach. Badacz przeanalizował wspomniane programy pod kątem obecności zagadnień wpisujących się w najnowsze trendy w rozwoju badań naukowych oraz odpowiadających najważniejszym wyzwaniom stojącym przed praktyką gospodarczą. W rezultacie tych analiz autorowi udało się m.in. ujawnić aktualne trendy w nauce i praktyce gospodarczej, nieuwzględnione $\mathrm{w}$ dostatecznym stopniu w programach kształcenia wiodących szkół wyższych. Tendencje te wpisują się w następujące zagadnienia: zarządzanie jakością, funkcja turystyczna miast i regionów, podejście sieciowe w badaniach regionalnych, turystyka współdzielenia, innowacje, przedsiębiorczość, nowe koncepcje zarządzania regionem i przedsiębiorstwami (Gołembski, 2016).

W tym kontekście warto też przywołać wnioski płynące z badań przeprowadzonych wśród absolwentów studiów I stopnia na kierunku turystyka i rekreacja (z lat 2008/2009 i 2009/2010), realizowanych w Akademii Wychowania Fizycznego w Warszawie, na Wydziale Wychowania Fizycznego i Sportu w Białej Podlaskiej. Wedle tych badań studentów na turystycznych kierunkach kształcenia charakteryzuje relatywnie wysoki poziom przedsiębiorczości, który w stosunku do ogółu polskich studentów można uznać nawet za ponadprzeciętny. Jednocześnie badane osoby były aktywne zawodowo (praca zarobkowa, poszerzanie kompetencji itp.), choć - jak piszą autorzy tego studium - wspomniani studenci „W mniejszym stopniu [...] angażowali się w działalność społeczną, organizacyjną czy naukową" (Buchta, Skiert, Sikora, 2012, s. 70-71).

Te ogólne informacje na temat przedsiębiorczości studentów turystyki warto uzupełnić o punkt widzenia pracodawców. Zgodnie z nim - w świetle wyników ogólnopolskich badań empirycznych, przeprowadzonych wśród przedsiębiorców z branży turystycznej-absolwenci studiów związanych z turystyką odznaczają się satysfakcjonującym poziomem wiedzy teoretycznej (wyuczonej), jednak zbyt niskim w stosunku do potrzeb doświadczeniem oraz poziomem asertywności i innowacyjności (Szymańska, 2009). Kwestia przygotowania kadr turystycznych tak, by mogły zaspokajać potrzeby rynku pracy, jest jednak trudna do jednoznacznego rozstrzygnięcia, ponieważ rezultaty innych badań sugerują z kolei, że kompetencje absolwentów studiów turystycznych w zakresie wiedzy są oceniane przez pracodawców stosunkowo nisko (Alejziak, 2014).

Należy jednak podkreślić, że pracodawcy oceniają wiedzę (a także umiejętności), jak można sądzić, przede wszystkim w kategoriach użyteczności praktycznej, rozpatrywanej pod kątem przydatności do realizacji konkretnych zadań zawodowych, a nie - co ważne, mając na uwadze cel niniejszego artykułu - szerokiego oglądu zjawiska turystyki i zachodzących w niej przemian. Jest to zresztą naturalne, zważywszy na fakt, że w wielu szkołach wyższych studia z zakresu turystki są postrzegane jako kształcenie o profilu praktycznym (nawet jeśli formalnie są realizowane jako studia akademickie), które mają przygotować absolwentów do wykonywania czynności związanych z szeroko pojętą obsługą ruchu turystycznego (por. Tokarz-Kocik, 2016). Niemniej jednak zdaniem osób reprezentujących jednocześnie środowisko akademickie i biznesowe „nie można [...] dopuścić do sytuacji, że absolwent wyższej uczelni posiada tylko wiedzę praktyczną i byłby tylko dobrym «rzemieślnikiem»" (Głąbiński, 2010, s. 259).

Warto też nadmienić, że nieco wyżej swoje własne kompetencje w zakresie wiedzy oceniają sami studenci. Nie znaczy to jednak, że są oni wobec siebie oraz reprezentowanych uczelni mało krytyczni, ponieważ ich samoocena jest we wszystkich aspektach wiedzy oraz umiejętności niższa od oczekiwanej (Skiert, Buchta, 2014). Aby w pełni scharakteryzować absolwentów studiów turystycznych, należy zaznaczyć, że nabywają oni wielu różnego rodzaju umiejętności, także społecznych/ miękkich (Łubkowska, Nadobnik, Tarnowski, Nowak, 2017), którymi oprócz kompetencji twardych powinni odznaczać się eksperci. Wyłaniający się z tego opisu obraz absolwenta studiów turystycznych (nawet jeśli pominie się kwestię zróżnicowania tego profilu ze względu na realizowany kierunek studiów czy specjalności) jest, jak się wydaje, bardzo skomplikowany. Wynika to jednak przede wszystkim ze złożoności zjawiska turystyki, a po części również z faktu, że na współczesnym rynku pracy premiuje się model tzw. elastycznej kariery zawodowej, charakteryzujący się m.in. gromadzeniem wiedzy i umiejętności (Bednarska, 
2013). Wszystko to zdaje się znajdować uzasadnienie w założeniu o szerokim przekrojowym zakresie wiedzy i innych kompetencji studentów na kierunkach kształcenia związanych z turystyką.

\section{METODA BADAŃ}

Cel niniejszego artykułu można wyrazić w postaci następującej hipotezy badawczej: studenci turystycznych kierunków kształcenia mogą dostrzegać trendy w sferze turystyki w sposób zgodny ze wskazaniami wyspecjalizowanych w tym zakresie ekspertów. Hipotezę tę uściślono, stawiając trzy pytania badawcze, które odnoszą się do osób studiujących na turystycznych kierunkach kształcenia:

1. Czy student ma wiedzę przedmiotową oraz umiejętności analityczne, dzięki którym jest w stanie objąć refleksją złożoną i wieloaspektową sferę turystyki?

2. Czy student potrafi w sposób krytyczny ustosunkować się do wskazanych przez ekspertów trendów będących odzwierciedleniem przemian dokonujących się w sferze turystyki?

3. Czy student potrafi twórczo rozszerzyć zbiór trendów będących odzwierciedleniem przemian zidentyfikowanych przez ekspertów, uzupełniając go o trafne wskazania wynikające z własnej wiedzy, osobistych doświadczeń, intuicji itp.?
Aby udzielić odpowiedzi na przedstawione pytania badawcze - a w konsekwencji zweryfikować postawioną hipotezę - pracę podzielono na trzy etapy, które w sposób skrótowy określono następująco:

1. Identyfikacja przyjętych przez ekspertów trendów związanych z przemianami zachodzącymi w ostatnich latach w sferze turystyki.

2. Dokonana przez studentów krytyczna ocena trendów zidentyfikowanych w etapie pierwszym, połączona z daną im możliwością uzupełnienia listy eksperckiej o inne trendy.

3. Porównanie ocen i propozycji studentów z aktualnymi trendami, wskazanymi przez ekspertów.

W pierwszej fazie przygotowano - na podstawie wskazań ekspertów European Travel Commission (ETC) oraz European Tourism Action Group (ETAG) z lat 2003 i 2006 - wykaz najważniejszych trendów obserwowanych w rzeczywistości społeczno-gospodarczej, a także ich prognozowanych wówczas skutków/znaczenia dla sektora turystyki. Wytypowano łącznie 10 z 11 opisanych $\mathrm{w}$ tych raportach trendów (rezygnacja $\mathrm{z}$ analizowania jednej kategorii trendów została wyjaśniona w dalszej części tekstu), a każdemu z nich przyporządkowano od trzech do siedmiu skutków/znaczeń. Analizy prowadzone $\mathrm{w}$ niniejszej pracy dotyczą więc 10 trendów oraz ich 47 skutków, które przedstawiono w tabeli 1.

W badaniu wykorzystano metodę sondażu diagnostycznego. W tym celu opracowano kwestionariusz, który składał się z trzech części. W części wstępnej

Tabela 1. Trendy oraz ich skutki/znaczenie dla sektora turystycznego według European Travel Commission (ETC) oraz European Tourism Action Group (ETAG)

\begin{tabular}{|c|c|c|c|}
\hline & Trendy & & Skutki/znaczenie (dla sektora turystycznego) \\
\hline \multirow{6}{*}{$\mathrm{I}$} & \multirow{6}{*}{$\begin{array}{c}\text { Demografia } \\
\text { Gwałtownie wzrośnie liczba osób } \\
\text { starszych. Seniorzy, zdrowsi niż } \\
\text { teraz, będą dysponować więk- } \\
\text { szymi środkami finansowymi. } \\
\text { Wcześniej zaczną przechodzić na } \\
\text { emeryturę. }\end{array}$} & 1 & Zwiększy się popyt na jakość, wygodę, bezpieczeństwo. \\
\hline & & 2 & Zwiększy się popyt na łatwy i szybki transport. \\
\hline & & 3 & Zwiększy się popyt na spokojne obiekty rozrywkowe. \\
\hline & & 4 & Zwiększy się popyt na produkty dla osób podróżujących pojedynczo. \\
\hline & & 5 & Zwiększy się popyt w miesiącach przed sezonem i po nim. \\
\hline & & 6 & $\begin{array}{l}\text { W marketingu będzie się odchodzić od podkreślania wieku na rzecz } \\
\text { akcentowania komfortu. }\end{array}$ \\
\hline \multirow{4}{*}{ II } & \multirow{4}{*}{$\begin{array}{c}\text { Zdrowie } \\
\text { Świadomość zdrowotna będzie } \\
\text { wzrastać. }\end{array}$} & 1 & $\begin{array}{l}\text { Kierunki podróży postrzegane jako mniej korzystne dla zdrowia będą } \\
\text { rzadziej wybierane niż dotychczas. }\end{array}$ \\
\hline & & 2 & $\begin{array}{l}\text { Popyt na oferty wyjazdów wakacyjnych, podczas których przewidziano } \\
\text { wyłącznie kąpiele słoneczne, będzie nadal malał. }\end{array}$ \\
\hline & & 3 & $\begin{array}{l}\text { Coraz popularniejsze będą wakacje aktywne, a popyt na obiekty spełniające } \\
\text { takie zapotrzebowanie będzie wzrastał. }\end{array}$ \\
\hline & & 4 & Popyt na produkty związane z odnową biologiczną będzie wzrastał. \\
\hline \multirow{3}{*}{ III } & \multirow{3}{*}{$\begin{array}{c}\text { Świadomość i edukacja } \\
\text { Podniesie się średni poziom } \\
\text { wykształcenia. }\end{array}$} & 1 & Zwiększy się popyt na produkty specjalistyczne. \\
\hline & & 2 & $\begin{array}{l}\text { Do imprez zorganizowanych i wakacji indywidualnych zostaną włączone } \\
\text { elementy sztuki, kultury, historii. }\end{array}$ \\
\hline & & 3 & $\begin{array}{l}\text { Zauważalna stanie się potrzeba lepszego i bardziej kreatywnego } \\
\text { przekazywania informacji. }\end{array}$ \\
\hline
\end{tabular}


Tabela 1. (cd.)

\begin{tabular}{|c|c|c|c|}
\hline & Trendy & & Skutki/znaczenie (dla sektora turystycznego) \\
\hline \multirow{6}{*}{ IV } & \multirow{6}{*}{$\begin{array}{l}\text { Technologie informatyczne } \\
\text { Nadal będzie wzrastać } \\
\text { znaczenie sieci WWW } \\
\text { (szukanie informacji, } \\
\text { zakupy przez Internet). }\end{array}$} & 1 & $\begin{array}{l}\text { Dostępność informacji turystycznej o kierunkach podróży i produktach będzie } \\
\text { sprzyjać porównywaniu ofert i w ten sposób intensywni wpłynie na } \\
\text { konkurencję. }\end{array}$ \\
\hline & & 2 & $\begin{array}{l}\text { Doświadczeni turyści coraz częściej będą komponować własne wakacje } \\
\text { z dostępnych modułów, dokonując bezpośrednich rezerwacji. }\end{array}$ \\
\hline & & 3 & $\begin{array}{l}\text { Rola biura podróży będzie malała, gdyż zakup imprez zorganizowanych coraz } \\
\text { częściej odbywa się przez Internet. }\end{array}$ \\
\hline & & 4 & $\begin{array}{l}\text { Internet będzie coraz szybciej zmniejszać rolę krajowych organizacji turystycznych } \\
\text { i izb turystyki. }\end{array}$ \\
\hline & & 5 & $\begin{array}{l}\text { Dostępność linków do usługodawców będzie coraz ważniejsza jako warunek } \\
\text { sukcesu stron internetowych. }\end{array}$ \\
\hline & & 6 & $\begin{array}{l}\text { W związku z rosnącym znaczeniem bezpieczeństwa bardziej krytyczni turyści } \\
\text { będą mieli większą potrzebę dokonywania bezpiecznych rezerwacji online. }\end{array}$ \\
\hline \multirow{7}{*}{$\mathrm{V}$} & \multirow{7}{*}{$\begin{array}{c}\text { Transport } \\
\text { Wzrośnie dostępność pociągów } \\
\text { szybkobieżnych oraz tanich linii } \\
\text { lotniczych, a jednocześnie ruch } \\
\text { na drogach krajowych będzie } \\
\text { utrudniony przez zatory. }\end{array}$} & 1 & Częściej wybierane będą łatwo dostępne i niedrogie miejsca na krótkie pobyty. \\
\hline & & 2 & Krótkie pobyty na wsi będą wypierane przez wyjazdy do dużych miast. \\
\hline & & 3 & Podróże koleją szybkobieżną będą bardziej popularne niż loty rejsowe. \\
\hline & & 4 & $\begin{array}{l}\text { Duża ruchliwość na drogach krajowych spowoduje utrudnienia w ruchu } \\
\left(,{ }^{\prime} \text { korki”). }\right.\end{array}$ \\
\hline & & 5 & Zainteresowanie wycieczkami autokarowymi będzie malało. \\
\hline & & 6 & Szczególnie u turystów po 50. roku życia wzrośnie zainteresowanie rejsami. \\
\hline & & 7 & $\begin{array}{l}\text { Trudność z dostępem do informacji o rozkładach podróży będzie miała negatywny } \\
\text { wpływ na wybór destynacji. }\end{array}$ \\
\hline \multirow{4}{*}{ VI } & \multirow{4}{*}{$\begin{array}{l}\text { Zrównoważony rozwój } \\
\text { Nadal będzie wzrastać } \\
\text { świadomość związana } \\
\text { z ochroną środowiska. }\end{array}$} & 1 & Regionalne destynacje zyskają na znaczeniu. \\
\hline & & 2 & $\begin{array}{l}\text { Turyści chętnie będą odwiedzać te miejsca, w których miejscowa ludność ochoczo } \\
\text { przyjmuje zwiększającą się liczbę turystów }\end{array}$ \\
\hline & & 3 & Turyści sami będą ponosić część kosztów związanych ze zrównoważonym rozwojem. \\
\hline & & 4 & Turystyka zrównoważona nie jest tożsama z ekoturystyką. \\
\hline \multirow{3}{*}{ VII } & \multirow{3}{*}{$\begin{array}{c}\text { Bezpieczeństwo } \\
\text { Z powodu zamachów } \\
\text { terrorystycznych, wojen, } \\
\text { kryzysów i zanieczyszczeń } \\
\text { turyści będą wystrzegać się } \\
\text { regionów postrzeganych za } \\
\text { niebezpieczne. }\end{array}$} & 1 & $\begin{array}{l}\text { Jakość wody zarówno w zbiornikach wodnych, jaki wody pitnejbędzie decydować } \\
\text { przy wyborze destynacji. }\end{array}$ \\
\hline & & 2 & $\begin{array}{l}\text { Wymagający turyści będą częściej niż dotychczas zgłaszać reklamacje, } \\
\text { w sytuacjach kiedy produkt nie spełnia standardów destynacji. }\end{array}$ \\
\hline & & 3 & Wzrosną koszty gwarancji bezpieczeństwa. \\
\hline \multirow{3}{*}{ VIII } & \multirow{3}{*}{$\begin{array}{c}\text { Czas wolny } \\
\text { Ze względu na fakt, że } \\
\text { społeczeństwo domaga się } \\
\text { większej ilości czasu wolnego } \\
\text { i wypoczynku, wolny dochód } \\
\text { będzie malał. }\end{array}$} & 1 & Wzrośnie potrzeba dostarczania tanich produktów. \\
\hline & & 2 & Wzrośnie potrzeba oferowania wypoczynku. \\
\hline & & 3 & Jeden długi urlop będzie częściej niż dotychczas zamieniany na kilka krótkich. \\
\hline \multirow{6}{*}{ IX } & \multirow{6}{*}{$\begin{array}{c}\text { Doznania } \\
\text { Zwiększają się oczekiwania tu- } \\
\text { rystów związane ze standardem } \\
\text { świadczonych usług, porów- } \\
\text { nania jakości do ceny. Turyści } \\
\text { częściej niż dotychczas otwarcie } \\
\text { mówią o swoich wymaganiach, } \\
\text { rosnących potrzebach, a później } \\
\text { skutecznie to weryfikują. }\end{array}$} & 1 & $\begin{array}{l}\text { Zwiększy się konkurencja na świadczone usługi turystyczne pod względem } \\
\text { atrakcyjności programu, destynacji; pojawią sięalternatywne sposoby wydawania } \\
\text { pieniędzy. }\end{array}$ \\
\hline & & 2 & $\begin{array}{l}\text { Kraje i regiony, które nie spełniają rosnących oczekiwań i standardów, staną się } \\
\text { mało atrakcyjne na dłuższy okres. }\end{array}$ \\
\hline & & 3 & $\begin{array}{l}\text { Zachowania klientów będą zróżnicowane (w jednym roku podróż zagraniczna, } \\
\text { w kolejnym krajowa; czasem jeden długi wyjazd, innym razem kilka krótszych). }\end{array}$ \\
\hline & & 4 & $\begin{array}{l}\text { Doświadczenie i krytyczne nastawienie skłoni turystów do podejmowania } \\
\text { podróży do miejsc z przeszłości („powrót do podstaw”). }\end{array}$ \\
\hline & & 5 & $\begin{array}{l}\text { Zwiększona mobilność turystów wpłynie pozytywnie na wynajem środków } \\
\text { transportu. }\end{array}$ \\
\hline & & 6 & $\begin{array}{l}\text { Coraz częściej turyści będą wybierać regiony, w których oferuje się zróżnicowaną, } \\
\text { pełną i całkowicie zrównoważoną koncepcję. }\end{array}$ \\
\hline
\end{tabular}


Tabela 1. (cd.)

\begin{tabular}{|c|c|c|c|}
\hline \multicolumn{2}{|c|}{ Trendy } & \multicolumn{2}{|r|}{ Skutki/znaczenie (dla sektora turystycznego) } \\
\hline \multirow{5}{*}{$x$} & \multirow{5}{*}{$\begin{array}{c}\text { Styl życia } \\
\text { Od kilkunastu lat obserwujemy } \\
\text { zmiany zachodzące w stylu ży- } \\
\text { cia, co ma znaczący wpływ na } \\
\text { postrzeganie potrzeb i zachowań } \\
\text { turystów. }\end{array}$} & 1 & $\begin{array}{l}\text { Spadnie zainteresowanie usługami typu BB (Bed \& Breakfast), postrzeganymi jako } \\
\text { mające niską jakość. }\end{array}$ \\
\hline & & 2 & $\begin{array}{l}\text { Zmiany stylu życia skutkują spadkiem zainteresowania zakupem imprez w formie } \\
\text { gotowych pakietów. }\end{array}$ \\
\hline & & 3 & $\begin{array}{l}\text { Imprezy turystyczne wzbogacone o nowe produkty i usługi będą chętniej } \\
\text { kupowane niż popularne obecnie. }\end{array}$ \\
\hline & & 4 & $\begin{array}{l}\text { Chętniej będą kupowane imprezy turystyczne, w których programie wypoczynek } \\
\text { zostanie połączony z możliwością uprawiania hobby. }\end{array}$ \\
\hline & & 5 & $\begin{array}{l}\text { Coraz powszechniejsza stanie się potrzeba posiadania "przystani”, stymulująca } \\
\text { bycie właścicielem drugiego domu. }\end{array}$ \\
\hline
\end{tabular}

Źródło: ETC, ETAG (2003); ETC (2006).

wskazano cel badania oraz sformułowano zaproszenie do udziału w nim. W części zasadniczej w formie tabelarycznej zawarto opis trendów (kolumna nr 1) oraz przypisanych im skutków/znaczenia (kolumna nr 2), dla każdego skutku/znaczenia pozostawiono pola do przypisania mu prawdopodobieństwa prognozy wystąpienia w skali globalnej (kolumna nr 3) oraz krajowej, tj. polskiej (kolumna nr 4). Wspomniane prawdopodobieństwo respondenci mogli wskazywać, posługując się następującą skalą Likerta: 1 - „całkowicie się zgadzam”, 2 - „zgadzam się", 3 - „nie mam zdania”, 4 - „nie zgadzam się", 5 - „,całkowicie się nie zgadzam". W tabeli dla każdego z 10 trendów wprowadzono także trzy dodatkowe wiersze, w których respondent mógł wpisać inne od podanych skutki/ znaczenia, których wystąpienie było - według niego - prawdopodobne w najbliższym czasie. W części końcowej umieszczono tzw. metryczkę, w której pytano o płeć oraz wiek ankietowanych, a zarazem podano dane kontaktowe do organizatora badania.

W celu realizacji drugiego etapu konieczne było wytypowanie próby z populacji generalnej osób, które podjęły studia związane z turystyką. Zdecydowano się $\mathrm{w}$ tym przypadku na dobór celowy, uznając za uzasadnione przeprowadzenie badań wśród studentów turystyki i rekreacji. Wspomniany kierunek, o czym świadczą plany studiów, wyróżnia bowiem daleko idąca interdyscyplinarność, a to z kolei dawało nadzieję, że studenci będą $w$ stanie ocenić trendy zidentyfikowane przez ekspertów, związane z różnymi obszarami aktywności w sferze turystyki. Badanie zrealizowano w dwóch szkołach wyższych - jednej państwowej, tj. Akademii Wychowania Fizycznego im. Bronisława Czecha w Krakowie, a drugiej prywatnej, ti. Szkole Głównej Turystyki i Hotelarstwa Vistula (dawniej funkcjonującej pod nazwą Szkoła Główna Turystyki i Rekreacji) w Warszawie. Zakres przestrzenny badań obejmował zatem Kraków i Warszawę - dwa ważne w skali Polski ośrodki akademickie, przygotowujące specjalistów do pracy na rynku turystycznym, natomiast zakres czasowy - rok akademicki 2017/2018 i 2018/2019.

W odniesieniu do ostatniej informacji należy wyjaśnić, że realizację badań, w których ramach przedkładano studentom różnych uczelni do oceny wskazane w tab. 1 trendy oraz ich skutki, rozpoczęto już w roku akademickim 2007/2008. W ciągu kolejnych lat modyfikowano jednak wykorzystane do badań narzędzie, tj. kwestionariusz. Wiązało się to nie tylko z nadawaniem mu stopniowo coraz bardziej przystępnej dla respondentów formy, ale przede wszystkim z jego rozszerzeniem. W pierwszych latach bowiem uczestnicy badań byli proszeni jedynie o ocenę skutków poszczególnych trendów wskazanych przez ekspertów, a dopiero w kolejnych mieli także możliwość „dopisania" własnych, prognozowanych skutków. Jest to jeden z powodów, dla których w niniejszej pracy zdecydowano się przedstawić wyniki badań jedynie $z$ dwóch lat. Drugim uzasadnieniem tej decyzji jest fakt, że wymienione $w$ tab. 1 trendy i ich skutki zdają się wciąż aktualne, co wynika, w gruncie rzeczy, z samej istoty trendu. Jak bowiem wcześniej wspomniano, trendy wiążą się w dużej mierze ze zmianami długookresowymi, a ich rozwój ma charakter ewolucyjny - w odróżnieniu od megatrendów, które w dużym stopniu wywołują rewolucyjne zmiany (Hajdas, Szabela-Pasierbińska, 2016) ${ }^{6}$.

Badaniami objęto w sumie 101 studentów, w większości reprezentujących studia uzupełniające magisterskie (wśród badanych było kilkunastu studentów nowej specjalności e-turystyka, realizowanej na drugim roku studiów I stopnia, którzy w odniesieniu do badań dotyczących technologii informatycznych dysponowali wiedzą $w$ tym zakresie nie mniejszą niż studenci II stopnia). Ze względu na to, że niektórzy z uczestników badania oddali kwestionariusze w znacznym stopniu niekompletne, do ostatecznej analizy wykorzystano dane pozyskane od 95 respondentów. Charakterystykę próby odzwierciedlają dane zebrane w tab. 2 . 
Tabela 2. Charakterystyka badanej próby studentów ( $\mathrm{n}=95)$ - reprezentowana uczelnia oraz płeć

\begin{tabular}{|c|c|c|c|}
\hline \multirow{2}{*}{ Uczelnia } & \multicolumn{2}{|c|}{ Płeć } & \multirow{2}{*}{ Brak } \\
\cline { 2 - 4 } Suma & Kobieta & Mężczyzna & \\
danych
\end{tabular}

Źródło: opracowanie własne.

Wśród 95 respondentów przeważały - pod kątem uczelni - osoby reprezentujące AWF w Krakowie, a ze względu na płeć - kobiety. Wszyscy respondenci, zgodnie z założeniem, realizowali studia na kierunku turystyka i rekreacja, na kilku specjalnościach. W przypadku AWF były to osoby kształcące się w następujących specjalnościach: a) na studiach magisterskich - zarządzanie biznesem turystycznym, zarządzanie ośrodkami SPA, outdoor project management, turystyka motywacyjna i biznesowa; b) na studiach licencjackich - e-turystyka; natomiast w SGTiH na studiach magisterskich - hotelarstwo i zarządzanie przemysłem spotkań. Uczestnicy w sposób naturalny - z uwagi na status studenta - zasadniczo byli w podobnym wieku.

\section{WYNIKI BADAŃ}

\subsection{DOKONANA PRZEZ STUDENTÓW OCENA PRAWDOPODOBIEŃSTWA WYSTAZPIENIA SKUTKÓW POSZCZEGÓLNYCH TRENDÓW WSKAZANYCH PRZEZ EKSPERTÓW}

Jak już wspomniano, na etapie prezentacji metody badań studenci oceniali każdy z trendów poprzez przypisanie do wszystkich odpowiadających mu, przewidywanych przez ekspertów ETC i ETAG skutków/znaczeń subiektywnie postrzeganego prawdopodobieństwa ich wystąpienia. Respondenci posługiwali się przy tym przedstawioną wcześniej w niniejszym artykule skalą. W ten sposób uczestnicy badania nie tylko jednak wyrażali swoje (co oczywiste - subiektywne) oceny, ale zarazem w sposób krytyczny oceniali prognozy ekspertów. Używając słowa "krytyczny", autorzy opracowania mają na myśli zarówno fakt, że studenci wedle swojej wiedzy oraz intuicji opiniowali sugestie specjalistów, jak i to, że mogli się z tymi sugestiami zgodzić (dokonywałoby się to poprzez przypisanie ocen na poziomie 1 i 2 ), zachować do nich stosunek neutralny (ocena równa 3 ), bądź zająć stanowisko odmienne (oceny 4 i 5). Na podstawie ocen studentów wyznaczono wielkości odnoszące się do podstawowych miar statystyki opisowej, które zebrano w tab. 3.
Analizując dane zebrane w tab. 3, można dojść do konkluzji, że oceny studentów są dość zbieżne z opiniami ekspertów. Może to wynikać albo z dużego zaufania studentów do wskazań specjalistów, albo ze zbieżności poglądów. Przekonują o tym w pierwszej kolejności stosunkowo niskie wartości średniej arytmetycznej. Co prawda, dla całego zbioru skutków mieszczą się one w przedziale od 1,4 do 3,5, lecz jeśli pominie się jedną skrajną ocenę na poziomie 3,5 (trend V, skutek 3), przedział zamyka się wartością 2,9 - a zatem w granicach ocen „całkowicie się zgadzam” $\mathrm{i}$ „zgadzam się", ewentualnie „nie mam zdania”. Do podobnego wniosku prowadzi analiza wyznaczonych wartości mediany oraz dominanty. Mediana w większości przypadków przyjęła wielkość 1 lub 2, niekiedy - 3, a tylko raz -4. Dominanta także najczęściej kształtowała się na poziomie 1 oraz 2, w kilku przypadkach -3, a w dwóch -4 .

W kontekście tych uwag warto jeszcze rozpatrzyć, w jakim stopniu studenci przejawiali skłonność do wystawiania ocen na poziomie 3. Takie oceny, oznaczające „brak zdania” w danej kwestii, można bowiem uznać za zachowawcze i sugerujące, że respondenci - z racji braku wystarczającej wiedzy lub z innych powodów - nie mają wyrobionego zdania na temat prawdopodobieństwa wystąpienia danego skutku. Należy zatem zwrócić uwagę na fakt, że w całej badanej zbiorowości w odniesieniu do wszystkich 47 skutków "trójki” zostały wystawione łącznie 691 razy, podczas gdy teoretycznie mogły się pojawić 4465 razy - tak by się stało, gdyby wszyscy respondenci $(n=95)$ ocenili na 3 każdy z 47 skutków. Innymi słowy, skłonność studentów do wystawiania ocen neutralnych wynosi $15,5 \%$, a w konsekwencji - tendencja do zajmowania stanowiska (pozytywnego lub negatywnego) kształtuje się na poziomie $84,5 \%$. Wartość tego ostatniego wskaźnika wydaje się stosunkowo wysoka, co świadczy o śmiałości respondentów w wyrażaniu swojego zdania. Dodajmy przy tym, że spośród ankietowanych, którzy wybrali inną odpowiedź niż ",3”, stanowisko zgodne ze wskazaniami ekspertów (tj. oceny 1 i 2 ) zajęło $82,4 \%$, a odmienne (tj. oceny 4 i 5) - $17,6 \%$.

Podany, ogólny ogląd wyników nie oznacza jednak, że respondenci w sposób jednoznaczny podzielali sugestie ekspertów ETC i ETAG co do dokonujących się, czy też oczekiwanych przemian w sektorze turystycznym. 
W odniesieniu do każdego skutku wartość minimalna to 1, maksymalna z kolei - niemal każdorazowo 5. Obszar zmienności (rozstęp) ocen jest zatem bardzo wysoki, w zasadzie - maksymalny. W połączeniu z odchyleniem standardowym mieszczącym się w zakresie między 0,7 a 1,2 oraz współczynnikiem zmienności w granicach mniej więcej od $35 \%$ do $55 \%$ wskazuje to na znaczne rozproszenie ocen studentów wokół wartości średnich. Należy jednak dodać, że oceny w większości przypadków rozkładają się prawostronnie asymetryczne (niekiedy skośność jest bardzo silna), czyli ciążą w kierunku ocen niskich.

Analizując wstępnie omówione wyniki, należy również zwrócić uwagę na skutki, na których temat badani studenci mieli odmienne zdanie niż specjaliści z ETC i ETAG. Dotyczy to zwłaszcza następującego skutku: „Podróże koleją szybkobieżną będą bardziej popularne niż loty rejsowe". Warto w tym kontekście podkreślić, że opinie ekspertów, będące podstawą badania, zostały sformułowane w latach 2003 i 2006 na podstawie da-

Tabela 3. Ocena prawdopodobieństwa wystąpienia danego trendu wraz z określonym skutkiem/znaczeniem dla turystyki na świecie w świetle opinii ogółu badanych studentów (n = 95)

\begin{tabular}{|c|c|c|c|c|c|c|c|c|c|c|c|}
\hline \multirow{3}{*}{\multicolumn{2}{|c|}{$\begin{array}{c}\text { Trendy } \\
\text { oraz ich znaczenie/skutki } \\
\text { dla sektora turystycznego }\end{array}$}} & \multirow{2}{*}{\multicolumn{3}{|c|}{$\begin{array}{c}\text { Miary } \\
\text { tendencji centralnej }\end{array}$}} & \multicolumn{6}{|c|}{ Miary zróżnicowania } & \multirow{3}{*}{ 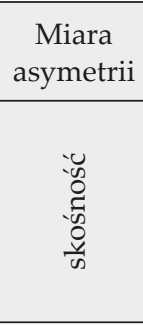 } \\
\hline & & & & & \multicolumn{5}{|c|}{ bezwzględne } & \multirow{2}{*}{ 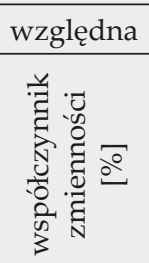 } & \\
\hline & & 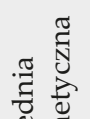 & $\underset{\widetilde{\pi}}{\widetilde{\pi}}$ & 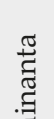 & 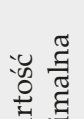 & 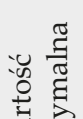 & 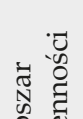 & 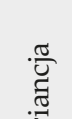 & 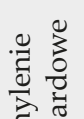 & & \\
\hline \multirow{6}{*}{ Demografia } & 1 & 1,6 & 1 & 1 & 1 & 5 & 4 & 0,70 & 0,8 & 50,0 & 1,8 \\
\hline & 2 & 1,6 & 1 & 1 & 1 & 5 & 4 & 0,71 & 0,8 & 52,4 & 1,7 \\
\hline & 3 & 2,4 & 2 & 2 & 1 & 5 & 4 & 1,06 & 1,0 & 41,9 & 0,5 \\
\hline & 4 & 2,9 & 3 & 2 & 1 & 5 & 4 & 1,18 & 1,1 & 37,9 & 0,1 \\
\hline & 5 & 2,2 & 2 & 2 & 1 & 5 & 4 & 1,08 & 1,0 & 46,9 & 0,8 \\
\hline & 6 & 2,2 & 2 & 1 & 1 & 5 & 4 & 1,36 & 1,2 & 52,9 & 0,7 \\
\hline \multirow{4}{*}{$\begin{array}{c}\text { II } \\
\text { Zdrowie }\end{array}$} & 1 & 2,3 & 2 & 1 & 1 & 5 & 4 & 1,50 & 1,2 & 53,7 & 0,7 \\
\hline & 2 & 2,5 & 2 & 2 & 1 & 5 & 4 & 1,50 & 1,2 & 49,2 & 0,4 \\
\hline & 3 & 1,6 & 1 & 1 & 1 & 5 & 4 & 0,70 & 0,8 & 51,6 & 1,6 \\
\hline & 4 & 1,6 & 1 & 1 & 1 & 5 & 4 & 0,80 & 0,9 & 56,6 & 1,9 \\
\hline \multirow{3}{*}{$\begin{array}{c}\text { III } \\
\text { Świadomość } \\
\text { i edukacja }\end{array}$} & 1 & 2,0 & 2 & 2 & 1 & 5 & 4 & 0,90 & 0,9 & 46,0 & 0,7 \\
\hline & 2 & 2,0 & 2 & 2 & 1 & 5 & 4 & 0,90 & 0,9 & 46,9 & 1,0 \\
\hline & 3 & 1,6 & 1 & 1 & 1 & 5 & 4 & 0,70 & 0,8 & 51,9 & 1,6 \\
\hline \multirow{6}{*}{$\begin{array}{c}\text { IV } \\
\text { Technologie } \\
\text { informatyczne }\end{array}$} & 1 & 1,4 & 1 & 1 & 1 & 5 & 4 & 0,60 & 0,8 & 55,5 & 2,4 \\
\hline & 2 & 1,6 & 1 & 1 & 1 & 5 & 4 & 0,70 & 0,8 & 52,0 & 1,7 \\
\hline & 3 & 2,0 & 2 & 1 & 1 & 5 & 4 & 1,30 & 1,1 & 57,4 & 0,9 \\
\hline & 4 & 2,5 & 2 & 3 & 1 & 5 & 4 & 1,30 & 1,1 & 45,9 & 0,3 \\
\hline & 5 & 1,9 & 2 & 2 & 1 & 5 & 4 & 0,80 & 0,9 & 43,3 & 0,7 \\
\hline & 6 & 2,0 & 2 & 2 & 1 & 5 & 4 & 1,00 & 1,0 & 49,2 & 0,9 \\
\hline \multirow{7}{*}{$\begin{array}{c}\text { V } \\
\text { Transport }\end{array}$} & 1 & 2,3 & 2 & 2 & 1 & 4 & 3 & 1,20 & 1,1 & 48,8 & 0,4 \\
\hline & 2 & 2,9 & 3 & 3 & 1 & 5 & 4 & 1,10 & 1,0 & 35,1 & $-0,1$ \\
\hline & 3 & 3,5 & 4 & 4 & 1 & 5 & 4 & 1,00 & 1,0 & 28,4 & $-0,6$ \\
\hline & 4 & 2,0 & 2 & 3 & 1 & 5 & 4 & 1,20 & 1,1 & 54,8 & 0,9 \\
\hline & 5 & 2,2 & 2 & 3 & 1 & 4 & 3 & 1,10 & 1,0 & 46,2 & 0,5 \\
\hline & 6 & 2,2 & 2 & 3 & 1 & 4 & 3 & 0,80 & 0,9 & 41,0 & 0,5 \\
\hline & 7 & 2,2 & 2 & 3 & 1 & 5 & 4 & 0,90 & 1,1 & 49,7 & 0,9 \\
\hline \multirow{4}{*}{$\begin{array}{c}\text { VI } \\
\text { Zrównoważony } \\
\text { rozwój }\end{array}$} & 1 & 2,4 & 2 & 2 & 1 & 4 & 3 & 0,70 & 0,8 & 34,9 & 0,0 \\
\hline & 2 & 2,5 & 2 & 2 & 1 & 5 & 4 & 1,20 & 1,1 & 43,8 & 0,6 \\
\hline & 3 & 2,6 & 3 & 2 & 1 & 5 & 4 & 0,90 & 0,9 & 35,3 & 0,4 \\
\hline & 4 & 2,4 & 2 & 2 & 1 & 4 & 3 & 0,90 & 0,9 & 39,4 & 0,2 \\
\hline
\end{tabular}


Tabela 3. (cd.)

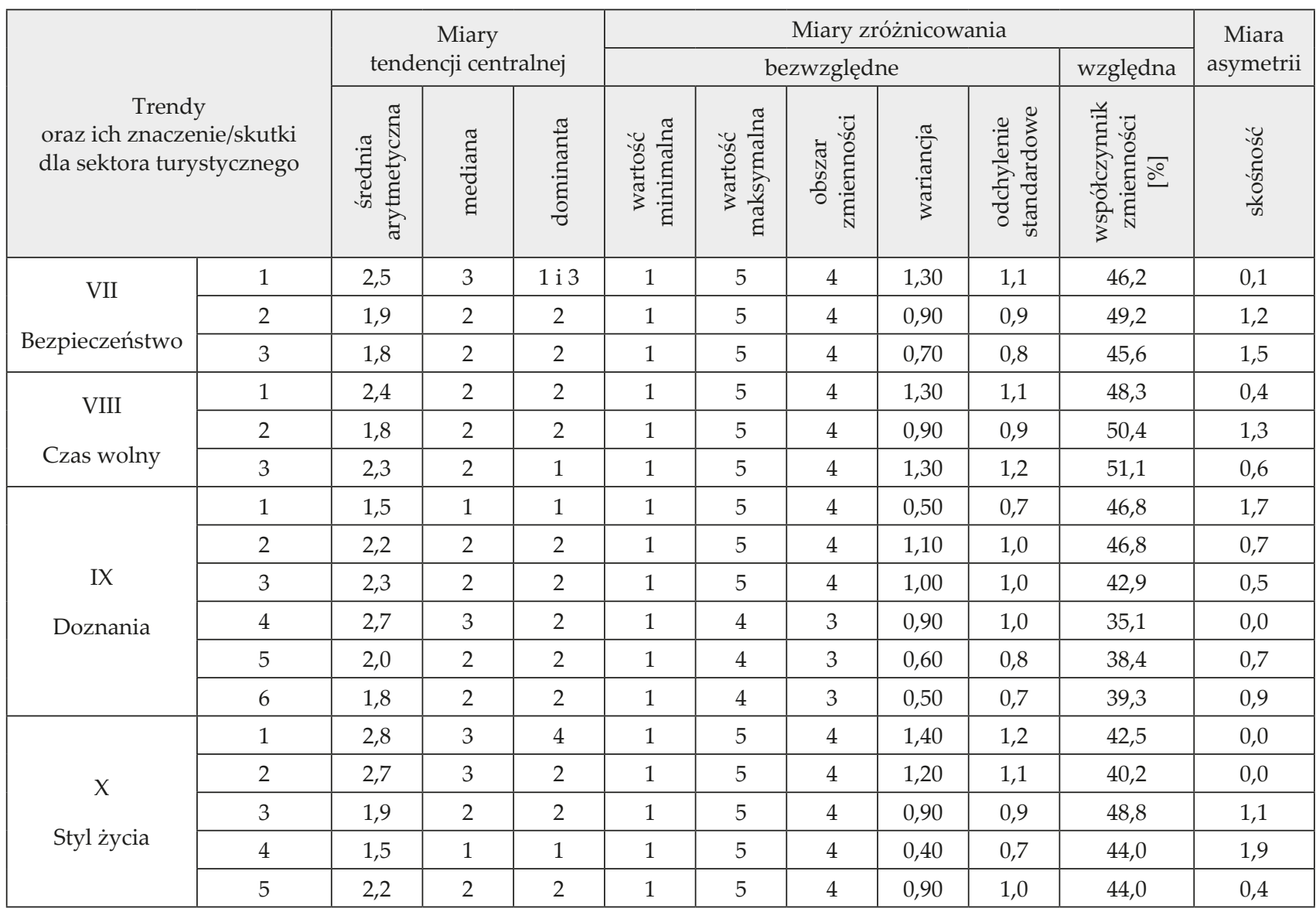

Źródło: opracowanie własne.

nych dostępnych na początku pierwszej dekady XX w. Respondenci z kolei dokonywali oceny kilkanaście lat później, dysponując już wiedzą o rzeczywistym rozwoju pewnych zjawisk, co do których wskazani eksperci formułowali jedynie prognozy. Dlatego też spostrzeżenia studentów, np. na temat struktury zapotrzebowania turystów na usługi transportowe z uwzględnieniem ich rodzaju, można ocenić pozytywnie - jako rezultat samodzielnego, krytycznego spojrzenia na zawarta $\mathrm{w}$ rozpatrywanym zbiorze tezę.

Zgromadzone $\mathrm{w}$ trakcie badań dane poddano także analizie mającej na celu ujawnienie ewentualnego zróżnicowania opinii respondentów, biorąc pod uwagę ich płeć. Przygotowano w tym celu analogiczne do zawartego $\mathrm{w}$ tab. 3 zestawienie podstawowych miar statystyki opisowej, przy czym opracowano je oddzielnie dla kobiet i mężczyzn. Wstępna analiza wielkości odnoszących się do wskazanego zbioru miar nie ujawniła jednak w sposób jednoznaczny istnienia wpływu płci na oceny przypisane poszczególnym trendom, czy też skutkom. W ramach poszczególnych trendów niektóre skutki uzyskały bowiem nieco wyższe oceny $\mathrm{w}$ grupie kobiet, inne $\mathrm{z}$ kolei - $\mathrm{w}$ grupie mężczyzn. Uwagę zwraca jednak fakt, że kobiety były w swoich opiniach bardziej zdecydowane, $t z n$. relatywnie rzadziej nadawały rozpatrywanym skutkom noty na poziomie 3. W całej grupie kobiet "trójki" pojawiły się w 12,2\% możliwych przypadków, podczas gdy analogiczny wskaźnik w grupie mężczyzn przyjął wartość $15,4 \%$.

Opisując budowę kwestionariusza, zaznaczono, że respondenci przypisywali każdemu rozpatrywanemu skutkowi prawdopodobieństwo jego wystąienia nie tylko w skali globalnej (te dane omówiono we wcześniejszej części artykułu), ale także krajowej, czyli w odniesieniu do sektora turystycznego w Polsce. Nie porównując danych dotyczących tych dwóch zbiorów odpowiedzi w sposób szczegółowy, warto odnotować - odwołując się do podstawowej miary tendencji centralnej - że w zbiorze 47 ocenianych skutków tylko w stosunku do 7 wyższy poziom średniej arytmetycznej uzyskały wskazania dotyczące skali globalnej, w 1 przypadku były one równe sobie (przy zaokrągleniu do jednego miejsca po przecinku), a dla 39 skutków wyższe noty przyznano wskazaniom dla Polski. Wydaje się zatem, że nieco wyższe prawdopodobieństwo wystąpienia większości skutków respondenci przypisują skali ogólnoświatowej niż krajowej, przy czym należy dodać, że różnice pomiędzy wielkościami średnimi były stosunkowo nieduże. 
Tabela 4. Liczba oryginalnych skutków/znaczeń dla sektora turystycznego, przypisanych do poszczególnych trendów przez ogół studentów według płci

\begin{tabular}{|c|c|c|c|c|c|c|}
\hline \multirow{3}{*}{\multicolumn{2}{|c|}{ Trendy w sektorze turystycznym }} & \multicolumn{5}{|c|}{ Liczba podanych znaczeń/skutków } \\
\hline & & \multirow{3}{*}{$\begin{array}{c}\text { Ogółem } \\
76\end{array}$} & \multicolumn{4}{|c|}{ w tym } \\
\hline & & & \multicolumn{2}{|c|}{ kobiety } & \multicolumn{2}{|c|}{ mężczyźni } \\
\hline I & Demografia & & 52 & $68,4 \%$ & 24 & $31,6 \%$ \\
\hline II & Zdrowie & 51 & 41 & $80,4 \%$ & 10 & $19,6 \%$ \\
\hline III & Świadomość i edukacja & 50 & 40 & $80,0 \%$ & 10 & $20,0 \%$ \\
\hline IV & Technologie informatyczne & 60 & 46 & $76,7 \%$ & 14 & $23,3 \%$ \\
\hline $\mathrm{V}$ & Transport & 37 & 29 & $78,4 \%$ & 8 & $21,6 \%$ \\
\hline $\mathrm{VI}$ & Zrównoważony rozwój & 36 & 30 & $83,3 \%$ & 6 & $16,7 \%$ \\
\hline VII & Bezpieczeństwo & 51 & 40 & $78,4 \%$ & 11 & $21,6 \%$ \\
\hline VIII & Czas wolny & 39 & 29 & $74,4 \%$ & 10 & $15,6 \%$ \\
\hline IX & Doznania & 29 & 23 & $79,3 \%$ & 6 & $20,7 \%$ \\
\hline$x$ & Styl życia & 45 & 40 & $88,9 \%$ & 5 & $11,1 \%$ \\
\hline \multicolumn{2}{|c|}{ Suma } & 474 & 370 & - & 104 & - \\
\hline
\end{tabular}

Źródło: opracowanie własne.

Rozważając ewentualne kryteria różnicujące odpowiedzi studentów, warto odwołać się także do wyników badań pilotażowych, które zrealizowano w roku akademickim 2014/2015 i 2015/2016. Studia te zostały przeprowadzone $\mathrm{z}$ wykorzystaniem nieco innego kwestionariusza (niektóre $z$ trendów były opisane poprzez inne skutki; nie było także możliwości wpisywania własnych propozycji skutków) wśród osób realizujących studia licencjackie (III rok) i magisterskie (II rok) w Wyższej Szkole Ekonomii, Prawa i Nauk Medycznych im. prof. E. Lipińskiego w Kielcach na kierunku ekonomia ze specjalnością ekonomia menedżerska. Były to zatem studia o charakterze nieturystycznym, lecz $\mathrm{w}$ ich programie znajdowały się także przedmioty związane $\mathrm{z}$ turystyką albo stricte turystyczne (w ramach wykładu monograficznego lub przedmiotu ekonomika turystyki). Rezultaty tych badań wskazuja że wartości średniej arytmetycznej mieszczą się $\mathrm{w}$ podobnym przedziale jak w przypadku studentów turystyki i rekreacji - ich zakres rozciąga się między 1,3 a 3,3. Jednocześnie w przypadku większej liczby skutków średnią arytmetyczną oszacowano na poziomie 3,0 lub wyższym. Wyniki w obu próbach okazały się podobne także pod względem wartości mediany i dominanty (w kieleckiej grupie studentów najczęściej wynosiły one także 1 lub 2), lecz znacząco różniły się w odniesieniu do skłonności do wystawiania ocen neutralnych, czyli wyboru odpowiedzi „3" („,nie mam zdania”). Jak już zostało nadmienione, wśród studentów z Krakowa i Warszawy ta skłonność wynosiła $13,5 \%$, a w przypadku studentów z Kielc oszacowano ją na poziomie $6,4 \%$. W tym sensie studenci ekonomicznego kierunku kształcenia okazali się bardziej zdecydowani.

\subsection{ROZWINIĘCIE PRZEZ STUDENTÓW ZBIORU WSKAZYWANYCH PRZEZ EKSPERTÓW SKUTKÓW POSZCZEGÓLNYCH TRENDÓW}

Dotychczasowa analiza wyników badań sugeruje, że respondenci przejawiali raczej skłonność do akceptowania tych przemian dokonujących się w sektorze turystycznym, które wymieniali eksperci. Taka daleko idąca zgodność opinii studentów i ekspertów nie jest jednak wyrazem biernej postawy tych pierwszych $i$ ich nieumiejętności zajęcia własnego stanowiska, czy też braku krytycyzmu. Okazało się bowiem, że uczestnicy badań uzewnętrznili swój krytyczny stosunek do zaprezentowanego im zbioru skutków, uzupełniając go i samodzielnie wskazując wiele oczekiwanych przez nich przemian $w$ sektorze turystycznym. Takich oryginalnych, wpisanych w kwestionariusze skutków było stosunkowo dużo - 474. Trzeba jednak zaznaczyć, że nie każdy respondent dopisał oczekiwane skutki; uczynily to w sumie 63 osoby, przy czym niektóre z nich wpisały następstwa w odniesieniu do niemal wszystkich trendów. Liczbę podanych przez studentów, dodatkowych skutków - z uwzględnieniem rozróżnienia płci wpisujących - zaprezentowano w tab. 4.

Analizując przedstawione dane, można zauważyć, że liczba zaproponowanych przez studentów skutków jest zróżnicowana: najmniej wpisano ich dla trendu pn. "doznania" (29), najwięcej - dla trendu pn. „demografia” (76). Wyjaśnienie przyczyn tego stanu rzeczy wykraczałoby poza ramy niniejszego tekstu, choć może to sugerować, że istnieją obszary, w których studenci czują się „mocniejsi”, mają większą wiedzę/intuicję i chętniej się nią dziela, oraz obszary, w których czują się bardziej niepewnie i są mniej skłonni do formułowania 
wypowiedzi. Uwagę zwraca jednak również fakt, że wśród 63 osób, które dokonały jakiegokolwiek wpisu, zdecydowanie przeważały kobiety - było ich aż 48 , czyli 76,3\%. Mając to na względzie, należy zauważyć, że w przypadku ośmiu trendów kobiety dokonały wpisów w liczbie większej, niż wynikałoby to z ich udziału w ogólnej liczbie respondentów, którzy pozytywnie odpowiedzieli na zaproszenie do wskazania innych skutków niż wynikające z opinii ETC i ETAG. Najbardziej widoczne w podanej kategorii było to w ramach trendu pn. „styl życia”. W tym przypadku aż 35 spośród 40 wpisów należało do kobiet. Wydaje się to dobrą podstawą do postawienia dwóch hipotez, których weryfikacja wymagałaby jednak odrębnych badań. Zgodnie z pierwszą studentki przejawiają większą niż mężczyźni skłonność do dzielenia się swoimi opiniami $\mathrm{w}$ kwestii przemian zachodzących lub przewidywanych w sektorze turystycznym. Druga hipoteza zakłada, że skłonność do wyrażania tego typu opinii jest zróżnicowana w zależności od dziedziny, której one dotyczą.

Nie przywołując w tym miejscu wszystkich skutków wskazanych przez uczestników badań (gwoli przypomnienia - było ich 474), autorzy opracowania skoncentrują się jedynie na tych skutkach, które dotyczą wybranych trendów, opisanych jako: "technologie informatyczne" oraz „doznania”. Wybór tych trendów ma charakter arbitralny, jednak został on podyktowany chęcią porównania trendów przynależących do obszarów rzeczywistości znacząco różniących się między sobą. W tym względzie "technologie informatyczne" reprezentują zjawiska współczesne, nowoczesne, ścisłe - i przez to, być może, bliższe studentom, jako osobom młodym (pokolenie Z). Z kolei „doznania” odnoszą się raczej do ponadczasowego, humanistycznego spojrzenia na otaczającą człowieka rzeczywistość oraz na jego potrzeby i pragnienia.

W tab. 5 i 6 przedstawiono skutki wskazane przez badanych studentów $\mathrm{w}$ ramach podanych wcześniej trendów. Skutki te, dla przejrzystości, pogrupowano, a ich charakterystyczne podzbiory opisano poprzez uogólniające kategorie. Trzeba jednak nadmienić, że ten zaproponowany sposób klasyfikowania nie jest jednym możliwym, ponieważ niektóre z podanych skutków odnoszą się do różnych aspektów danego trendu. Należy także zwrócić uwagę, że tabele nie zawierają w tym przypadku danych o prawdopodobieństwie wystąpienia poszczególnych skutków, ponieważ te dopisane samodzielnie przez respondentów były zwykle wskazywane przez pojedyncze osoby, a zarazem ich wystąpienie było przez nie oceniane jako bardzo możliwe $(1$ - „całkowicie się zgadzam” lub 2 - „zgadzam się"). W takim właśnie ujęciu w tab. 5 zaprezentowano skutki odnoszące się do trendu pn. „technologie informatyczne".

Analizując zawartość tab. 5, trzeba zauważyć, że studenci w znaczący sposób rozwinęli zbiór skutków, jaki został im przedłożony do oceny. Uzupełnili go o 60 wskazań, które niewątpliwie odnoszą się do kilku istotnych współcześnie zjawisk obserwowanych w związku z rozwojem technologii informacyjno-komunikacyjnych. Zwrócili uwagę na kwestie fundamentalne, wypowiadając się w sprawie roli tradycyjnych i nowoczesnych biur podróży, a także pytając o wpływ wskazanych technologii na zainteresowanie

Tabela 5. Skutki/znaczenie wskazane samodzielnie przez studentów w odniesieniu do trendu nr 4 „technologie informatyczne”

\begin{tabular}{|c|c|c|c|}
\hline Lp. & Nr respondenta & Znaczenie/skutki dla sektora turystycznego & Kategoria \\
\hline 1 & 70 & $\begin{array}{l}\text { biura podróży dalej będą miały duże znaczenie, z racji niechęci wielu osób do zaku- } \\
\text { pów online }\end{array}$ & \multirow{5}{*}{$\begin{array}{l}\text { Tradycyjne } \\
\text { biura podróży }\end{array}$} \\
\hline 2 & 4 & $\begin{array}{l}\text { zostanie jednak duża część osób, którzy będą preferowali kontakt osobisty z pra- } \\
\text { cownikiem biura, kawa, herbata itd. }\end{array}$ & \\
\hline 3 & 82 & biura podróży podniesieniu standardu sprzedaż bezpośrednia & \\
\hline 4 & 76 & $\begin{array}{l}\text { wzrost liczby rezerwacji i zakupów biletów przez internet prowadzi do spadku } \\
\text { zatrudnienia (biuro podróży, kasy) }\end{array}$ & \\
\hline 5 & 56 & wzrośnie znaczenie konsultantów, doradców online & \\
\hline 6 & 55 & łatwość komunikacji z biurem podróży / miejscem wypoczynku & \multirow{7}{*}{$\begin{array}{l}\text { Dostęp } \\
\text { do informacji }\end{array}$} \\
\hline 7 & 76 & wzrost świadomości klientów, poprzez łatwy dostęp do informacji & \\
\hline 8 & 98 & $\begin{array}{l}\text { najważniejsza w internecie jest dostępność ofert w jednym miejscu i możliwość ich } \\
\text { porównania oraz łatwość w zorganizowaniu swojego wyjazdu bez konieczności } \\
\text { wychodzenia z domu }\end{array}$ & \\
\hline 9 & 53 & $\begin{array}{l}\text { wzrośnie liczba portali branżowych zajmujących się porównywaniem i rezerwacja- } \\
\text { mi i zakupem }\end{array}$ & \\
\hline 10 & 72 & wzrost znaczenia stron informacyjnych i lokalnych ocen (np. TripAdvisor) & \\
\hline 11 & 57 & aplikacje gdzie można zobaczyć i porównać oferty & \\
\hline 12 & 55 & dostępność informacji o bezpieczeństwie w miejscu wypoczynku & \\
\hline
\end{tabular}


Tabela 5. (cd.)

\begin{tabular}{|c|c|c|c|}
\hline Lp. & Nr respondenta & Znaczenie/skutki dla sektora turystycznego & Kategoria \\
\hline 13 & 52 & wzrost wpływu social media na turystykę & \multirow{4}{*}{$\begin{array}{l}\text { Media } \\
\text { społecznościowe }\end{array}$} \\
\hline 14 & 91 & większy wpływ social media na rozpoznawalność i popyt biura podróży, obiektu itp. & \\
\hline 15 & 85 & wzrost znaczenia opinii umieszczonej w sieci & \\
\hline 16 & 54 & poszukiwanie informacji u turystów i oferty indywidualne & \\
\hline 17 & 66 & bardziej wymagający klienci & \multirow{5}{*}{$\begin{array}{l}\text { Samodzielna } \\
\text { organizacja } \\
\text { podróży }\end{array}$} \\
\hline 18 & 51 & lepsze dostosowanie wyjazdów do potrzeb indywidualnych & \\
\hline 19 & 89 & $\begin{array}{l}\text { wzrost popytu na podróże we własnym zakresie (opartym na dużej wiedzy } \\
\text { o danym miejscu, otrzymanej za pomocą internetu) }\end{array}$ & \\
\hline 20 & 62 & popyt na samodzielną organizację swoich wyjazdów & \\
\hline 21 & 5 & polacy moim zdaniem preferują zakupić cały pakiet - organizowane imprezy & \\
\hline 22 & 92 & rozwój aplikacji mobilnych & \multirow{13}{*}{$\begin{array}{l}\text { Aplikacje } \\
\text { mobilne }\end{array}$} \\
\hline 23 & 53 & wzrośnie ilość aplikacji mobilnych ułatwiających podróżowanie & \\
\hline 24 & 72 & wzrost znaczenia aplikacji w sektorze turystyki & \\
\hline 25 & 90 & większy popyt na aplikacje turystyczne & \\
\hline 26 & 58 & rozwój aplikacji turystycznych spowoduje spadek wśród usług pilotów i przewodników & \\
\hline 27 & 64 & $\begin{array}{l}\text { zmniejszenie zainteresowania na przewodnika - człowieka i wzrost zainteresowa- } \\
\text { nia aplikacjami przewodnickimi + np. google z funkcją rozpoznawania obiektów + } \\
\text { informacje o nim }\end{array}$ & \\
\hline 28 & 67 & wzrośnie popyt na aplikacje przewodnickie & \\
\hline 29 & 77 & wzrost popytu na aplikacje mobilne rezerwacyjne czy formy przewodników & \\
\hline 30 & 61 & wzrost komfortu przy rezerwacji wycieczek & \\
\hline 31 & 89 & możliwość dokonywania zakupu lub rezerwacji przez telefon komórkowy & \\
\hline 32 & 67 & wzrośnie popyt na aplikacje rekreacyjne & \\
\hline 33 & 72 & $\begin{array}{l}\text { wzrost zapotrzebowania na interaktywne zwiedzanie wystaw, spadek zaintereso- } \\
\text { wania „nudnymi” muzeami }\end{array}$ & \\
\hline 34 & 78 & $\begin{array}{l}\text { nie będzie potrzeby korzystania z przewodników i pilotów bo wszystko można } \\
\text { znaleźć w tel. }\end{array}$ & \\
\hline 35 & 60 & $\begin{array}{l}\text { dostęp do internetu jest coraz częściej wyznacznikiem przy wyborze destynacji } \\
\text { a później zadowolenia }\end{array}$ & \multirow{5}{*}{$\begin{array}{l}\text { Nowoczesne } \\
\text { technologie } \\
\text { w miejscu } \\
\text { realizacji } \\
\text { podróży }\end{array}$} \\
\hline 36 & 8 & wzrost popytu na cyfryzację miejsc odwiedzanych, tj. internet na miejscu & \\
\hline 37 & 83 & mniejsze zapotrzebowanie na wyposażenie pokoi (TV), ważniejsze staje się wi-fi & \\
\hline 38 & 100 & $\begin{array}{l}\text { wybór miejsc noclegowych oferujących szeroką gamę możliwości korzystania } \\
\text { z nowoczesnych technologii informatycznych wzrośnie }\end{array}$ & \\
\hline 39 & 90 & $\begin{array}{l}\text { wzrost znaczenia technologii w hotelach, miejscach turystycznych, p. informa- } \\
\text { cyjnych }\end{array}$ & \\
\hline 40 & 63 & skierowanie ofert głównie do młodych & \multirow{3}{*}{$\begin{array}{l}\text { Specyficzne } \\
\text { segmenty } \\
\text { klientów }\end{array}$} \\
\hline 41 & 94 & $\begin{array}{l}\text { wiele seniorów boi się wyjazdów niezaplanowanych przez specjalistów (bariera } \\
\text { językowa, bariera technologiczna - nieznajomość obsługi) }\end{array}$ & \\
\hline 42 & 58 & $\begin{array}{l}\text { rozwój aplikacji pozwalających łamać bariery podczas zwiedzania dla osób niepeł- } \\
\text { nosprawnych, niewidomych }\end{array}$ & \\
\hline 43 & 51 & zmniejszenie się integracji ogólnej w czasie wyjazdów & \multirow{2}{*}{$\begin{array}{l}\text { Kontakty } \\
\text { międzyludzkie } \\
\text { podczas podróży }\end{array}$} \\
\hline 44 & 51 & zwiększenie integracji wśród ludzi o tych samych zainteresowaniach & \\
\hline 45 & 64 & $\begin{array}{l}\text { mniej osób będzie wychodziło z domu ze wzgl. na możliwości odbycia wirtualnej } \\
\text { podróży }\end{array}$ & \multirow{4}{*}{$\begin{array}{l}\text { Zainteresowanie } \\
\text { podejmowaniem } \\
\text { podróży }\end{array}$} \\
\hline 46 & 65 & $\begin{array}{l}\text { liczba wycieczek może maleć ze względu na sposobność zobaczenia tego samego } \\
\text { w internecie }\end{array}$ & \\
\hline 47 & 63 & rozleniwienie społeczeństwa & \\
\hline 48 & 45 & $\begin{array}{l}\text { ludzie będą więcej czasu spędzać w domu, bo będzie coraz więcej pracy przez } \\
\text { internet }\end{array}$ & \\
\hline
\end{tabular}


Tabela 5. (cd.)

\begin{tabular}{|c|c|l|c|}
\hline Lp. & Nr respondenta & \multicolumn{1}{|c|}{ Znaczenie/skutki dla sektora turystycznego } & Kategoria \\
\hline 49 & 58 & rola biur podróży ograniczy się do organizowania incentive travel \\
\hline 50 & 52 & wyparcie sieci hotelowych przez ekonomię współdzielenia \\
\hline 51 & 62 & popyt na slow live wśród turystów \\
\hline 52 & 71 & praktycznie zanikną przedsiębiorstwa nie posiadające strony internetowej \\
\hline 53 & 66 & walka o klienta (obniżanie cen, podnoszenie standardów) \\
\hline 54 & 95 & wzrośnie zaufanie do internetowych biur podróży & Inne \\
\hline 55 & 61 & rozwój marketingu organizatorów turystyki & zapotrzebowanie na reklamę w internecie czy w usługach typu google \\
\hline 56 & 77 & -jeśli go stać - sprzedaż impulsywna \\
\hline 57 & 78 & $\begin{array}{l}\text { Internet musi zredukować chęć poznawcza, aby zobaczyć coś na żywo, nie tylko na } \\
\text { zdjęciu }\end{array}$ & \\
\hline 58 & 85 & wzrost msc pracy dla informatyków, programistów \\
\hline 59 & 63 & wzrost działalności hakerów, wirusów, niebezpieczeństwo przelewów \\
\hline 60 & 90 &
\end{tabular}

Źródło: opracowanie własne (zachowano pisownię oryginalną).

podejmowaniem podróży - w zwyczajowym tego słowa znaczeniu - oraz o dominującą formułę realizacji wyjazdów przez współczesnych turystów. Zabrali także głos w kwestii przemian zachodzących w obszarze dostępu do informacji, uwzględniając m.in. zagadnienie komunikacji dokonującej się między wspólnotami konsumentów - m.in. poprzez media społecznościowe. Nie zabrakło też wypowiedzi na temat tego, jaką rolę odgrywają aplikacje mobilne w zaspokajaniu potrzeb współczesnych turystów oraz w świadczeniu udogodnień, jakich oczekują oni w miejscu realizacji podróży. Studenci - jako grupa - odwołali się również do aktualnych problemów, które kryją się za takimi terminami, jak „ekonomia współdzielenia” czy „slow life”. Odczytując te dość optymistyczne wyniki, trzeba mieć jednak na uwadze, że rozpatrywane tu wpisy zostały dokonane przez pojedyncze osoby, co jest wyrazem aktywności i spostrzegawczości konkretnych studentów, a nie całej ich zbiorowości.

W analogiczny sposób w tab. 6 zebrano skutki dotyczące trendu pn. „doznania”, w odniesieniu do którego - jak już wspomniano - uczestnicy badań dokonali najmniejszej liczby wpisów. W tym przypadku wskazań studentów, które pogrupowano na pięć kategorii, jest znacznie mniej, a ponadto są one mniej zróżnicowane. Co ważniejsze jednak, biorąc pod uwagę sposób sformułowania niektórych wskazań, wątpliwe wydaje się zakwalifikowanie ich do obszaru doznań. O ile bowiem wskazania zgrupowane w kategorie "charakter doznań", ,jakość i innowacyjność usług” oraz "model organizacji podróży" wpisują się w szeroko pojętą kwestię doświadczeń turysty, o tyle wskazania ujęte w dwie pozostałe kategorie - tj. „reklamacje i działalność przedsiębiorstw" i „inne" - trudno interpretować w kontekście przeżyć doznawanych przez osoby odbywające podróż i odczuwanych przez nie emocji. Skłania to do postawienia tezy, że zdolności studentów do obserwowania, dostrzegania i artykułowania przemian zachodzących $\mathrm{w}$ sektorze turystyki zależą od dziedziny, której te przemiany dotyczą. Do podobnego przekonania prowadzi wgląd we wskazania studentów dotyczące pozostałych dziewięciu trendów, lecz ich omówienie wykraczałoby znacznie poza ramy tego opracowania.

Tabela 6. Skutki/znaczenie wskazane samodzielnie przez studentów w odniesieniu do trendu nr 9 „doznania”

\begin{tabular}{|c|c|l|c|}
\hline Lp. & Nr respondenta & \multicolumn{1}{|c|}{ Znaczenie/skutki dla sektora turystycznego } & Kategoria \\
\hline 1 & 83 & potrzeba wycieczek ekstremalnych & \\
\cline { 1 - 3 } 2 & 85 & popyt na ekstremalne doznania & \multirow{2}{*}{$\begin{array}{c}\text { Charakter } \\
\text { doznań }\end{array}$} \\
\hline 3 & 90 & wzrost popytu na miejsca egzotyczne, zaskakujące, nowoczesne & \\
\hline 4 & 91 & większa chęć poznawania nowych nieznanych miejsc & \\
\hline 6 & 72 & przesyt rynku idealnością i standardem i zapotrzebowanie na ,autentyczność" & \\
\hline 7 & 72 & wzrost znaczenia małych gospodarstw/pensjonatów & \\
\hline
\end{tabular}


Tabela 6. (cd.)

\begin{tabular}{|c|c|c|c|}
\hline Lp. & Nr respondenta & Znaczenie/skutki dla sektora turystycznego & Kategoria \\
\hline 8 & 77 & podnoszenie się jakości usług & \multirow{9}{*}{$\begin{array}{l}\text { Jakość } \\
\text { i innowacyjność } \\
\text { usług }\end{array}$} \\
\hline 9 & 78 & wyższa jakość usług & \\
\hline 10 & 1 & wzrost wymagań turystów odnośnie obiektów noclegowych, transportu & \\
\hline 11 & 95 & większy komfort transportu i pobytu & \\
\hline 12 & 95 & lepsza jakość obsługi, posiłków itp. & \\
\hline 13 & 63 & podniesienie poziomu usług hoteli / przewoźników & \\
\hline 14 & 58 & wzrost popytu na dobra luksusowe & \\
\hline 15 & 65 & większy popyt na innowacyjne atrakcje & \\
\hline 16 & 11 & $\begin{array}{l}\text { coraz częściej turyści wybierają regiony z unikatowymi lub np. unowocześ- } \\
\text { nionymi szklanymi mostami nad przepaścią coś co da dodatkowy zastrzyk } \\
\text { adrenaliny + miejsce egzotyczne }\end{array}$ & \\
\hline 17 & 82 & większa potrzeba wycieczek egzotycznych na "własną rękę" & \multirow{3}{*}{$\begin{array}{l}\text { Model organizacji } \\
\text { podróży }\end{array}$} \\
\hline 18 & 58 & turyści rzadziej będą organizować wakacje samodzielnie za tanie pieniądze & \\
\hline 19 & 58 & spadnie znaczenie trampingu & \\
\hline 20 & 5 & ludzie stają się też świadomi swoich praw i częściej zgłaszają reklamacje & \multirow{5}{*}{$\begin{array}{l}\text { Reklamacje } \\
\text { i działalność } \\
\text { przedsiębiorstw }\end{array}$} \\
\hline 21 & 71 & wzrośnie liczba reklamacji w biurach podróży & \\
\hline 22 & 61 & $\begin{array}{l}\text { większe zainteresowanie składaniem reklamacji za imprezę niespełniającą } \\
\text { oczekiwań klienta }\end{array}$ & \\
\hline 23 & 77 & wzrost prób wyłudzenia odszkodowań & \\
\hline 24 & 61 & bankructwo małych przedsiębiorstw tur. & \\
\hline 25 & 66 & skrupulatne, dokładne szukanie ofert i sprawdzanie programów & \multirow{5}{*}{ Inne } \\
\hline 26 & 66 & powrót do danego miejsca po zadowoleniu z programu & \\
\hline 27 & 67 & wiele możliwości podróżowania samolot, samochód itp. & \\
\hline 28 & 67 & konkurencyjność wśród przewoźników & \\
\hline 29 & 85 & wraz ze wzrostem konkurencji spadną ceny usług turystycznych & \\
\hline
\end{tabular}

Źródło: opracowanie własne (zachowano pisownię oryginalną).

\subsection{PORÓWNANIE SKUTKÓW POSZCZEGÓLNYCH TRENDÓW \\ SAMODZIELNIE WSKAZANYCH PRZEZ STUDENTÓW \\ Z OPINIAMI PRACOWNIKÓW NAUKOWYCH I PRZEDSTAWICIELI BIUR PODRÓŻY}

Opisane w poprzednim rozdziale badania były prowadzone w latach 2017-2019. Studia te stanowiły jednak kontynuację realizowanego z różnym natężeniem od 2010 r. projektu badawczego, który chociaż miał nieco inny charakter i odmienne cele, $\mathrm{w}$ dużym stopniu korespondował $\mathrm{z}$ przedstawioną $\mathrm{w}$ niniejszym opracowaniu problematyką. Wydaje się, że wcześniejsze badania wpisują się w cele nakreślone $\mathrm{w}$ tym artykule, dlatego też zostaną one pokrótce zaprezentowane $\mathrm{w}$ dalszej części tekstu i wykorzystane do udzielenia odpowiedzi na postawione $w$ nim pytania badawcze.

Badania realizowano w latach 2010-2012 wśród osób zatrudnionych w rzeszowskich biurach podróży oraz pracowników i studentów Wyższej Szkoły Informatyki i Zarządzania (WSIiZ) w Rzeszowie. Badania wykonano w ramach realizacji eksperymentalnej formuły prowadzenia przedmiotu polityka turystyczna (na ostatnim roku studiów magisterskich na kierunku turystyka i rekreacja), w części zajęć, która dotyczyła wpływu megatrendów cywilizacyjnych na funkcjonowanie rynku turystycznego. Badania te miały też związek z pracami nad opracowywaną wówczas (oraz wypróbowywaną na zajęciach ze studentami) nową metoda, obecnie znaną w literaturze jako sekwencyjna analiza trendów turystycznych (Alejziak, 2012). Zarówno sama metoda, jak i udostępnione wyniki badań, zostały później wykorzystane w pracach magisterskich trójki studentów WSIiZ (zob. Gałek, 2011; Kusiak, 2011; Pichura, 2011).

W opisanych w opracowaniu badaniach z 2011 r. wyodrębniono trzy grupy respondentów. Pierwszą byli pracownicy Katedry Gospodarki Turystycznej (KGT) w WSIiZ w Rzeszowie, od których uzyskano 17 prawidłowo wypełnionych formularzy ankietowych w wersji papierowej. Drugą grupę badawczą stanowiło 35 studentów drugiego roku studiów uzupełniających magisterskich na kierunku turystyka i rekreacja na tej samej uczelni. Od tych ankietowanych uzyskano wyczerpu- 

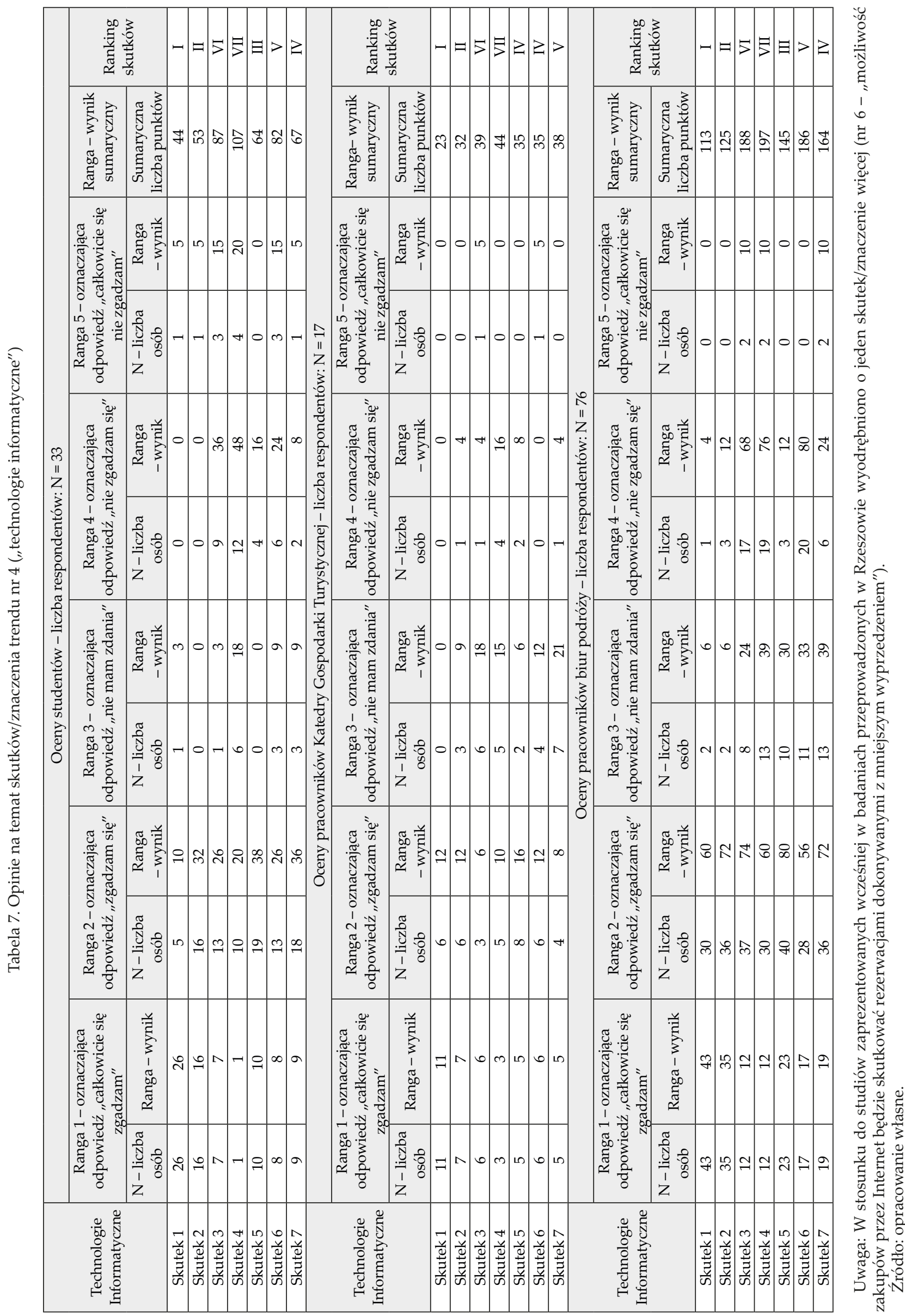
jące odpowiedzi w 33 kwestionariuszach (pozostałe 2 były niekompletnie wypełnione, w związku z czym zrezygnowano $\mathrm{z}$ uwzględnienia ich w badaniach). Ostatnią i największą grupą respondentów byli pracownicy rzeszowskich biur podróży, którzy wypełnili formularz ankiety udostępniony im za pośrednictwem strony internetowej www.webankieta.pl. W ten sposób pozyskano 93 kwestionariusze, z czego do dalszych analiz zakwalifikowano 76 (17 zostało odrzuconych ze względu na brak niektórych odpowiedzi).

Aby przeprowadzić zbiorcze analizy, nadano rangę każdej z rozpatrywanych zmiennych oraz uzyskanych od respondentów odpowiedzi, zgodnie z założeniem, że im niższa wartość wyniku sumarycznego (suma rang cząstkowych), tym większe prawdopodobieństwo zaistnienia danego skutku w ramach analizowanego trendu. Natomiast im wyższa wartość wyniku sumarycznego, tym prawdopodobieństwo to jest mniejsze. Takie działanie podjęto $\mathrm{w}$ celu utworzenia rankingu prawdopodobieństwa zaistnienia poszczególnych skutków, a pośrednio - ustalenia, jaki wpływ na rynek turystyczny maja poszczególne trendy. Wynik można uzyskać, porządkując skutki od „,1" do „,n”, gdzie „,n” określa liczbę analizowanych skutków, oraz przyporządkowując kolejność od „1” do „nx”, gdzie „nx” oznacza kolejność prawdopodobieństwa zgodnie z przyjętymi założeniami. W efekcie skutek, który uzyskał najniższą wartość wyniku sumarycznego, był oznaczany jako „I" i cechowało go największe prawdopodobieństwo zaistnienia. Z kolei skutek, którego dotyczyły wartości najwyższe, miał najmniejsze prawdopodobieństwo. W dalszej części artykułu przedstawiono wyniki dokonanych w ten sposób analiz oceny dwóch trendów - „technologie informatyczne” oraz „doznania”.

W tab. 7 przedstawiono opinie studentów, wykładowców Katedry Gospodarki Turystycznej oraz pracowników rzeszowskich biur podróży. Największy poziom zgodności z opiniami ekspertów ETC i ETAG w przypadku wszystkich badanych odnotowano w odniesieniu do skutku pierwszego, mówiącego, że coraz łatwiejszy dostęp do informacji turystycznej pozwoli uzyskać więcej danych o kierunku docelowym, a także porównać ceny, przez co będzie bardziej intensywnie wpływać na konkurencję. Natomiast za najmniej prawdopodobny badani uznali skutek czwarty („Internet będzie coraz szybciej zmniejszać także rolę krajowych organizacji turystycznych i izb turystyki"). Wszystkie odpowiedzi zaprezentowano w tab. 7. Warto zauważyć, że w zakresie skutków bardziej prawdopodobnych opinie studentów były w dużym stopniu zbieżne $z$ ocenami wykładowców, natomiast w przypadku skutków mniej prawdopodobnych - bardziej zbliżone do deklaracji pracowników biur podróży.

Do ciekawych wniosków można dojść, porównując średnią wartość wskazań dotyczących prawdopodobieństwa poszczególnych skutków, którą się obli- cza, dzieląc wartość sumaryczną wszystkich wskazań w poszczególnych grupach przez ich liczebność. W przypadku pierwszego skutku kształtuje się ona następująco: studenci - 1,333 (44 : 33); wykładowcy $-1,353$ (23:17), pracownicy biur podróży -1,487 (113 : 76). We wszystkich grupach wyniki są zatem dość podobne. Natomiast w przypadku skutku czwartego wynoszą odpowiednio: dla studentów - 3,242 (107 : 33); dla wykładowców - 2,588 (44 : 17); dla pracowników biur podróży - 2,592 (197: 76).

Analiza zbiorcza uzyskanych wyników, polegająca na określeniu rangi (kolejności) prawdopodobieństwa analizowanych skutków (tab. 8) ujawnia, że wszystkie grupy badanych wskazały dokładnie takie same skutki w przypadku tych, które powinny ich zdaniem zaistnieć z prawdopodobieństwem najwyższym (skutek nr 1) oraz najniższym (skutek nr 7). Warto również zauważyć, że w przypadku opinii studentów i pracowników biur turystycznych mamy do czynienia z dokładnie taką samą hierarchią prawdopodobieństwa. W grupie pracowników KGT opinie dotyczące skutków nr 5, 6, 7 były nieco inne, chociaż w żadnym przypadku nie różniły się o więcej niż jedno miejsce w rankingu.

Tabela 8. Trend nr 4 ,technologie informatyczne" - zbiorcze zestawienie rankingów skutków

\begin{tabular}{|c|c|c|c|}
\cline { 2 - 4 } \multicolumn{1}{c|}{} & $\begin{array}{c}\text { Pracownicy } \\
\text { KGT }\end{array}$ & Studenci & $\begin{array}{c}\text { Pracownicy } \\
\text { biur podróży }\end{array}$ \\
\hline Skutek 1 & I & I & I \\
\hline Skutek 2 & II & II & II \\
\hline Skutek 3 & VI & VI & VI \\
\hline Skutek 4 & VII & VII & VII \\
\hline Skutek 5 & IV & III & III \\
\hline Skutek 6 & IV & V & V \\
\hline Skutek 7 & V & IV & IV \\
\hline
\end{tabular}

Źródło: opracowanie własne.

W stosunku do opinii na temat trendów technologicznych (informatycznych) zupełnie inaczej przedstawiały się wyniki badań dotyczące trendu nr 9 pn. „doznania", w którego przypadku wystąpiły wyraźnie większe zróżnicowania opinii w rankingach skutków. Nie przedstawiając tu już szczegółowych danych, autorzy pragną tylko zwrócić uwagę (tab. 9), że o ile na pierwszym miejscu w przypadku wszystkich badanych grup wskazano skutek nr 1, o tyle za najmniej prawdopodobny studenci uznali skutek nr 5, podczas gdy pracownicy KGT - skutek nr 3, a pracownicy biur podróży - skutek $\mathrm{nr}$ 4. Wydaje się zatem, że intuicyjne oceny wystawione przez badanych studentów nie odbiegały znacząco od wskazań wynikających z wiedzy i doświadczenia pracowników akademickich oraz pracowników biur podróży, tj. osób zawodowo zajmujących się obserwowaniem sytuacji na rynku turystycznym. 
Tabela 9. Trend nr 9 „doznania”

- zbiorcze zestawienie rankingów skutków

\begin{tabular}{|c|c|c|c|}
\cline { 2 - 4 } \multicolumn{1}{c|}{} & $\begin{array}{c}\text { Pracownicy } \\
\text { KGT }\end{array}$ & Studenci & $\begin{array}{c}\text { Pracownicy biur } \\
\text { podróży }\end{array}$ \\
\hline Skutek 1 & I & I & I \\
\hline Skutek 2 & IV & III & IV \\
\hline Skutek 3 & VI & IV & III \\
\hline Skutek 4 & II & V & VI \\
\hline Skutek 5 & IV & VI & V \\
\hline Skutek 6 & V & II & II \\
\hline
\end{tabular}

Źródło: opracowanie własne.

\section{ZAKOŃCZENIE}

Dzięki zawartym w pracy rozważaniom można wskazać specyficzne cechy studentów jako osób mogących uczestniczyć w pracach ukierunkowanych na identyfikację i przewidywanie przemian zachodzących w sferze turystyki. Zanim jednak zostanie przedstawiona wyłaniająca się $\mathrm{w}$ ten sposób charakterystyka studenta jako eksperta, należy zauważyć, że wyniki zaprezentowanych badań świadczą o słuszności przyjętych na wstępie założeń. Badani studenci okazali się bowiem osobami krytycznie oceniającymi świat wokół nich, czego wyrazem było nadawanie niskich ocen prawdopodobieństwa niektórym skutkom uznanym przez ekspertów za znaczące. Ponadto uczestniczący w badaniu studenci potrafili odwołać się do zasobów wiedzy zdobytej podczas studiów oraz do prowadzonych przez siebie obserwacji otaczającej rzeczywistości, uzupełniając otrzymany do oceny zestaw skutków o własne wskazania. Warto w tym kontekście dodać - choć tego wątku nie rozwinięto $\mathrm{w}$ ramach zaprezentowanej analizy - że poddani badaniu studenci najchętniej dopisywali w kwestionariuszu skutki w ramach tych trendów, które były zbieżne $\mathrm{z}$ wybraną przez nich $\mathrm{w}$ toku studiów specjalizacją (było to $\mathrm{np}$. widoczne zwłaszcza wśród studentów specjalności zarządzanie ośrodkami SPA, którzy chętnie wypowiadali się na tematy dotyczace trendu „zdrowie”). Wspomniana charakterystyka studenta jako osoby predestynowanej do tworzenia projekcji dotyczącej sfery turystyki zostanie natomiast rozpatrzona $\mathrm{w}$ odniesieniu do postawionych pytań badawczych.

Na pierwsze pytanie badawcze („,Czy student ma wiedzę przedmiotową oraz umiejętności analityczne, dzięki którym jest w stanie objąć refleksją złożoną i wieloaspektową sferę turystyki?") można odpowiedzieć twierdząco, z dwoma zastrzeżeniami. Rezultaty badań potwierdziły, że studenci mają wiedzę, która sprawia, że ze zrozumieniem podchodzą do niezwykle złożonej, turystycznej rzeczywistości i w dużej mierze są w stanie zająć konkretne stanowisko wobec różnych jej wymiarów. Dało się jednak odczuć - co można uznać za obserwację dość naturalną - że są obszary, w których uczestnicy badań czuli się pewniej i w związku z tym wypowiadali się o nich chętniej (np. demografia, technologie informatyczne), jak i takie, na temat których ich wypowiedzi były bardziej powściągliwe (np. doznania). Ponadto wspomniane umiejętności analityczne można uznać (przynajmniej na podstawie zreferowanych tu badań) raczej za miękkie: związane ze zdolnością do kojarzenia i łączenia pewnych zjawisk, czy też faktów. W toku przedstawionych w tym opracowaniu badań nie weryfikowano bowiem twardych umiejętności wspomnianego typu, związanych z przysposobieniem do realizacji zadań związanych z analityką rynku.

Na drugie pytanie badawcze („Czy student potrafi w sposób krytyczny ustosunkować się do wskazanych przez ekspertów trendów będących odzwierciedleniem przemian dokonujących się w sferze turystyki?") również można odpowiedzieć twierdząco. Co prawda, studenci najczęściej wybierali odpowiedzi „całkowicie się zgadzam" i ,zgadzam się" (potwierdziły to także badania porównawcze $\mathrm{w}$ grupach: studenci - pracownicy akademiccy - pracownicy biur podróży), ale trudno mieć do tego zastrzeżenia. Zwraca jednak uwagę fakt, że studenci relatywnie rzadko uznawali, że nie mają zdania na dany temat, a zatem okazali się wysoce skłonni do zajmowania własnego stanowiska.

Na trzecie pytanie badawcze („Czy student potrafi twórczo rozszerzyć zbiór trendów będących odzwierciedleniem przemian zidentyfikowanych przez ekspertów, uzupełniając go o trafne wskazania wynikające z własnej wiedzy, osobistych doświadczeń, intuicji itp.?") odpowiedź nie może być jednoznaczna. Z jednej strony obraz, który wyłonił się z całej badanej próby, wydaje się dość optymistyczny, gdyż studenci w ramach każdego z ocenianych trendów uzupełnili przedłożony im zestaw skutków o kilkadziesiąt własnych wskazań. Z drugiej jednak strony te kilkadziesiąt wskazań było rezultatem badania całej zbiorowości. Tak więc np. w ramach trendu piątego pn. "technologie informatyczne" studenci dopisali w kwestionariuszach 60 przewidywanych przez siebie skutków, jednak były to wskazania jednostkowe. Biorąc więc pod uwagę liczbę respondentów $(\mathrm{n}=95)$, łatwo zauważyć, że na każdego badanego studenta przypada przeciętnie 0,6 oryginalnego skutku. Taki wynik trzeba uznać za dość słaby, zważywszy na to, że mowa tu o niezwykle rozwojowym, zresztą nie tylko w sferze turystyki, zjawisku. Pomijając ewentualną (typową dla badań sondażowych) niechęć respondentów do podjęcia wysiłku umysłowego, uzewnętrzniającego się dokonaniem w kwestionariuszu samodzielnego, przemyślanego wpisu, wydaje się, że studenci jako zbiorowość 
są twórczy i ich obserwacje mogą stanowić celne uzupełnienie sugestii specjalistów, jednak wskazania przeciętnego (w znaczeniu: statystycznego) studenta nie są $\mathrm{w}$ tym względzie satysfakcjonujące. Tym samym studenci w pracy zespołowej jawią się jako wartościowi uczestnicy badań o charakterze burzy mózgów, lecz w celu przygotowania bardziej skonkretyzowanych projekcji niezbędna wydaje się stosowna selekcja wśród zbiorowości studentów. Takie spostrzeżenie pozwala z kolei uznać za zasadne włączanie studentów do badań wstępnych, projektowych, pilotażowych itp.

Na podstawie dokonanych obserwacji postawioną w niniejszej pracy hipotezę badawczą (,studenci turystycznych kierunków kształcenia mogą dostrzegać trendy w sferze turystyki w sposób zgodny ze wskazaniami wyspecjalizowanych w tym zakresie ekspertów") można zweryfikować pozytywnie, czyniąc to jednak z pewną ostrożnością. Ogólny obraz studentów, wyłaniający się z badań przedstawionych $\mathrm{w}$ niniejszym opracowaniu, zasługuje na dobrą ocenę: studenci jako zbiorowość okazali się śmiali, zdecydowani, twórczy, kreatywni; mieli wiele cennych obserwacji dotyczących otaczającej ich rzeczywistości i potrafili je wyartykułować w sposób przekonujący. Uśredniony obraz studenta jako jednostki jest jednak nieco inny. Ukazuje on osobę o szerokim zakresie wiedzy, lecz niezbyt skłonną do formułowania rozwiniętych wypowiedzi na temat oczekiwanych skutków poszczególnych trendów. Trzeba jednak pamiętać, że ten ostatni wniosek może być, choć po części, rezultatem obranej metody badań, która niektórych studentów mogła zachęcać do ujawnienia swoich opinii, a innych - nie. W świetle tych wyjaśnień wydaje się, że umiejętne angażowanie studentów jako ekspertów (organizacja badań zespołowych, atrakcyjna formuła realizacji badań, dowartościowanie uczestników itp.), może okazać się cennym elementem badań prowadzonych przez specjalistów.

Trzeba także na koniec podkreślić, że badani studenci oceniali trendy i przypisane im skutki wygenerowane przez ekspertów mniej więcej dziesięć lat wcześniej (w pierwszej dekadzie XX w.). Wynikało to z faktu, że obrana pierwotnie metoda badań stopniowo ewoluowała i ze względu na cele niniejszej pracy zasadne było przedstawienie wyników osiągniętych przy zastosowaniu najbardziej rozbudowanej postaci kwestionariusza. Niemniej jednak należy też mieć na uwadze, że poddane ocenom studentów trendy i ich skutki, jeżeli nieco straciły na wyrazistości, to nie zdezaktualizowały się w sposób istotny. Świadczy o tym raczej długookresowa natura samych trendów, stosunkowo ogólny sposób ich sformułowania, a także konfrontacja z bardziej aktualnymi zbiorami trendów, które przedstawiane są w literaturze przedmiotu. Co prawda, w ostatnich latach ukazało się wiele nowych raportów prognostycznych oraz prac analizujących trendy występujące na rynku turystycznym (m.in. Amadeus, 2020; CREST, 2019; CTD, 2018; EU, 2017; Expedia, 2017; Future Fundation, 2009; Geerts, 2018; Harwath HTL, 2015; KPMG, Movat, 2013; Mazars, 2018; Nordin, 2005; OECD, 2018, 2020; Scott, Gössling, 2015; UNWTO, 2011; WT\&TC, Bloomberg, 2019), jednak ich analiza wskazuje na to, że zasadniczo prognozy i trendy przedstawiane wcześniej były trafne i w większości przypadków należy się spodziewać ich kontynuacji.

\section{PRZYPISY}

${ }^{1}$ Istotę megatrendu dobrze ujął Muszyński (2006, s. 89), pisząc, że ,[...] termin ten cechują zjawiska, procesy i wydarzenia obejmujące główne dziedziny życia ludzkiego, a więc stosunki ekonomiczne, społeczne, polityczne, kulturowe oraz ludzką świadomość, które zyskały w procesie kształtowania i rozwoju charakter trwałych tendencji oddziałujących w coraz szerszym zakresie i głębszym przenikaniu na całą ludzkość oraz powstawały one przy różnych uwarunkowaniach, czynnikach i mechanizmach sprawczych, jako rezultat cywilizacyjnego rozwoju ludzkości i poczynając od drugiej połowy dwudziestego stulecia, nabierały coraz większego znaczenia i głębszego przenikania w życie społeczeństw". Ten temat szerzej omawia z kolej Naisbitt (1982). Mikrotrend oznacza zaś zjawiska zachodzące w małych społecznościach (często w opozycji do głównego nurtu), natomiast moda odnosi się do zjawisk o różnym zasięgu oddziaływania, lecz krótkotrwałych i często wykreowanych przez przedstawicieli biznesu, celebrytów itp. (Hajdas, Szabela-Pasierbińska, 2016).

${ }^{2}$ Często w literaturze jest też cytowany zaproponowany przez Cole'a (2007) podział, według którego wyróżniamy: prognozowanie, przewidywania, sondaż (badania eksperckie).

${ }^{3}$ Przegląd uczelni i kierunków kształcenia z zakresu turystyki został zawarty m.in. w pracy Długosza i Białego (2011).

${ }^{4}$ Kwestia multidyscyplinarnego charakteru studiów z zakresu turystyki jest omówiona np. w pracy: Ozimek, Rutkiewicz (2011).

${ }^{5} \mathrm{Na}$ marginesie tych uwag należy podkreślić, że wieloaspektowość studiów z zakresu turystyki nie jest zjawiskiem nowym, lecz charakteryzuje tego typu studia niemal od początku ich realizacji (zob. np. Kruczek, 1998).

${ }^{6}$ Wspomniane tu modyfikacje kwestionariusza są także powodem, dla którego - o czym już wcześniej wstępnie wspomniano - w niniejszej pracy pominięto analizy jednego z 11 badanych trendów, pn. „ekonomia”. W kolejnych latach bowiem w formularzu ankiety zmieniano zapisy dotyczące skutków/znaczenia tego właśnie trendu.

\section{BIBLIOGRAFIA}

Alejziak, B. (2014). Kwalifikacje i kompetencje pracowników turystyki. Próba diagnozy turystycznego rynku pracy. Folia Turistica, 32, 117-144.

Alejziak, W. (2012). Sekwencyjna analiza trendów turystycznych (SATT) jako instrument diagnozowania zmian w popycie turystycznym. Ekonomiczne Problemy Ustug, 82, 27-42.

Alejziak, W., Szczechowicz, B. (2019). Globalizacja a rozwój turystyki - implikacje dla planowania i polityki turystycznej. 
W: Uwarunkowania i plany rozwoju turystyki. Tom XXII: Planowanie i polityka turystyczna (s. 9-27). Poznań: Uniwersytet A. Mickiewicza, Bogucki - Wydawnictwo Naukowe.

Amadeus (2020). Future traveller tribes 2020. Pobrane z: http:// www.amadeus.com/travellertribes (25.03.2020).

Bednarska, M. (2013). Kierunek kształcenia a planowana kariera zawodowa - studium empiryczne kierunków związanych z turystyką. E-mentor, 4 (51). Pobrane z: http://www.e-mentor. edu.pl/artykul/index/numer/51/id/1039 (25.03.2020).

Borodako, K. (2008). Foresight w turystyce. Bariery wykorzystania i rozwoju. Warszawa: Wydawnictwo C.H. Beck.

Buchta, K., Skiert, M., Sikora, J. (2012). Przedsiębiorczość jako element przygotowania zawodowego studentów turystyki i rekreacji. Ekonomiczne Problemy Turystyki, 20, 59-73.

Chomątowska, B., Żarczyńska-Dobiesz, A. (2014). Pokolenie „Z" na rynku pracy - wyzwania dla zarządzania zasobami ludzkimi. Prace Naukowe Uniwersytetu Ekonomicznego we Wrocławiu, 350, 405-415. DOI: https://doi.org/10.15611/pn.2014.350.36

Coathup, D. (1999). Dominant actors in international tourism. International Journal of Contemporary Hospitality Management, 11 (2/3), 69-72. DOI: https://doi.org/10.1108/09596119910250689

Cole, S. (2007). Dare to dream: Bringing futures into planning. Journal of the American Planning Association, 67 (4), 372-383. DOI: https://doi.org/10.1080/01944360108976246

CREST (2019). The case for responsible travel: Trends \& statistics 2019. Pobrane z: https://www.responsibletravel.org/docs/ CaseforResponsibleTravel_2019_Web.pdf (22.03.2020).

CTD (2018). All change? The first report of the commission on travel demand the future of travel demand and the implications for policy and planning. Pobrane z: http://www.demand.ac.uk/wp-content/ uploads/2018/04/FutureTravel_report_final.pdf (20.02.2020).

Długosz, Z., Biały, Sz. (2011). Studia w zakresie turystyki na tle szkolnictwa wyższego w kraju. Przedsiębiorczość - Edukacja, 7, 346-360.

van der Duim, R., Ren, C., Jóhannesson, G.T. (2013). Ordering, materiality, and multiplicity: Enacting Actor-Network Theory in tourism. Tourism Studies, 11, 1-18. DOI: https://doi. org/10.1177/1468797613476397

EC (2009). Mapping foresight. Revealing how Europe and other world regions navigate into the future. Bruksela: European Commission. Pobrane z: http://www.forschungsnetzwerk. at/downloadpub/2009_efmn_mappingForesight_EU.pdf (21.02.2020).

ETC (2006). Tourism trends for Europe. Pobrane z: http://www. etc-corporate.org/resources/uploads/ETC_Tourism_Trends_ for_Europe_09-2006_ENG.pdf (10.02.2020).

ETC, ETAG (2003). Tourism trends for Europe. Pobrane z: http:// www.etc-corporate.org/images/uploads/Diptych\%20ETCETAG.pdf (6.10.2010).

EU (2017). Management and content provision for ICT and tourism business support portal. Pobrane z: https://ec.europa.eu/growth/ content/management-and-content-provision-ict-and-tourism-business-support-portal_en (6.12.2018).

Expedia (2017). Millennial traveller report: Why millennials will shape the next 20 years of travel. Pobrane z: https://travelblog. expedia.com.sg/wp-content/uploads/2017/03/Expedia-FutureFoundation-Report-Jan-2017-FINAL.pdf (10.05.2018).

Future Foundation (2009). Travel and tourism in 2020 prepared by the future foundation: The key drivers. Pobrane z: http://www. foresightfordevelopment.org/sobipro/55/822-travel-and-tourism-in-2020-prepared-by-the-future-foundation-the-key-drivers (17.04.2011).

Gałek, K. (2011). Wpływ megatrendów cywilizacyjnych na rozwój wspótczesnego rynku turystycznego (ze szczególnym uwzględnieniem trendów ekonomicznych i politycznych). Praca magisterska.
Promotor: W. Alejziak. Rzeszów: Wyższa Szkoła Informatyki i Zarządzania w Rzeszowie.

Geerts W. (red.) (2018). Megatrends shaping the future of travel 2018. Londyn: Euromonitor International.

Głąbiński, Z. (2010). Przygotowanie absolwentów kierunków i specjalności turystycznych do pracy w gospodarce turystycznej a oczekiwania rynku. W: S. Tanaś (red.), Nauka i dydaktyka w turystyce i rekreacji (s. 257-262). Łódź: Łódzkie Towarzystwo Naukowe.

Gołembski, G. (2016). Nowe formy kształcenia w obszarze turystyki. Folia Turistica, 41, 63-80. DOI: https://doi. org/10.5604/01.3001.0010.4004

Grabiński, T., Wydymus, S., Zeliaś, A. (1993). Metody prognozowania rozwoju społeczno-gospodarczego. Wyd. II, poprawione i uzupełnione. Kraków: Akademia Ekonomiczna.

Hajdas, M., Szabela-Pasierbińska, E. (2016). Metody przewidywania trendów w makrootoczeniu. Zeszyty Naukowe Uniwersytetu Ekonomicznego we Wrocławiu, 459, 232-244. DOI: https://doi. org/10.15611/pn.2016.459.22

Harwath HTL (2015). Tourism megatrends - 10 things you need to know about the future of tourism. Pobrane $\mathrm{z}$ : http://corporate. cms-horwathhtl.com/wp-content/uploads/sites/2/2015/12/ Tourism-Mega-Trends4.pdf (10.06.2016).

Inskeep, E. (1991). Tourism planning - an integrated and sustainable development approach. New York: Van Nostrand Reinhold.

KPMG, Movat (2013). Future State 2030: The global megatrends shaping governments. Toronto: KPMG and Mowat Centre.

Kruczek, Z. (1998). Kształcenie dla potrzeb turystyki w regionie małopolskim. Folia Turistica, 8, 5-16.

Kusiak, M. (2011). Wpływ megatrendów technologicznych i ekologicznych na funkcjonowanie rynku turystycznego. Praca magisterska. Promotor W. Alejziak. Warszawa: Wyższa Szkoła Informatyki i Zarządzania w Warszawie.

Łubkowska, W., Nadobnik, J., Tarnowski, M., Nowak, M.A. (2017). Samoocena wiedzy, umiejętności zawodowych i kompetencji społecznych studentów podstawą ewaluacji programu studiów kierunku turystyka i rekreacja. Prace Naukowe Akademii im. Jana Długosza w Częstochowie, XVI (4), 145-161. DOI: https:// doi.org/10.16926/kf.2017.16.43

Mazars (2018). Artificial intelligence: A game changer in the hospitality industry. Pobrane z: https://www.mazars.pl/content/ download/945503/49214764/version//file/Mazars_2018_AI_ in_Hospitality_Study.pdf (10.01.2019).

Muszyński, J., (2006). Społeczeństwo informacyjne. Szkice politologiczne. Toruń: Adam Marszałek.

Naisbitt, J. (1982). Megatrends. Ten new directions transforming our lives. Nowy Jork: Fortuna Publications.

Nordin, S. (2005). Tourism of tomorrow: Travel trends and forces change. Pobrane z: http://www.turism.se/media/Undersokningar\%20 av\%20varde/Tourism\%20of\%20tomorrow.pdf (20.05.2018).

OECD (2018). Analysing megatrends to better shape the future of tourism. Pobrane z: https://www.oecd-ilibrary.org/industry-and-services/analysing-megatrends-to-better-shape-the-future-of-tourism_d465eb68-en (12.09.2019)

OECD (2020). Tourism trends and policies 2020. Paris: OECD. Pobrane z: https://www.oecd.org/cfe/tourism/oecd-tourism-trends-and-policies-20767773.htm (20.03.2020). DOI: https:// doi.org/10.1787/6b47b985-en

Ozimek, I., Rutkiewicz, A. (2011). Interdyscyplinarność studiów na kierunku turystyka i rekreacja - przykład Międzywydziałowego Studium Turystki i Rekreacji SGGW w Warszawie. Studia i Materiaty CEPL w Rogowie, 13 (3/28), 28-33.

Pearce, P.L. (2005). The role of relationships in the tourist experience. W: W.F. Theobold (red.), Global tourism (s. 103-122). 
Wydanie 3. Burlington: Elsevier. DOI: https://doi.org/10.1016/ B978-0-7506-7789-9.50012-1

Penc, J. (1997). Strategie zarządzania. Perspektywiczne myślenie, systemowe działanie. Warszawa: Agencja Wydawnicza Placet.

Pichura, M. (2011). Wpływ megatrendów demograficznych i społeczno-kulturowych na rozwój wspótczesnego rynku turystycznego. Praca magisterska. Promotor: W. Alejziak. Rzeszów: Wyższa Szkoła Informatyki i Zarządzania w Rzeszowie.

Scott, D., Gössling, S. (2015). What could the next 40 years hold for global tourism? Tourism Recreation Research, 40 (3), 269-285. DOI: https://doi.org/10.1080/02508281.2015.1075739

Skiert, M., Buchta, K. (2014). Jakość kształcenia na kierunku turystyka i rekreacja w świetle oczekiwań rynku turystycznego. Prace Naukowe Uniwersytetu Ekonomicznego we Wrocławiu, 353, 145-154. DOI: https://doi.org/10.15611/pn.2014.353.13

Szymańska, E. (2009). Oczekiwania rynku turystycznego w zakresie kształcenia kadr. Economy and Management, 1, 133-140.

Tokarz-Kocik, A. (2016). Kształcenie kadr dla potrzeb obsługi ruchu turystycznego. Zeszyty Naukowe Uniwersytetu
Szczecińskiego. Ekonomiczne Problemy Turystyki, 2 (34), 377-385. DOI: https://doi.org/10.18276/ept.2016.2.34-31

UNWTO (2011). Tourism towards 2030 global overview. Pobrane z: https://www.globalwellnesssummit.com/wp-content/uploads/Industry-Research/Global/2011_UNWTO_Tourism_ Towards_2030.pdf (23.03.2018).

Wodejko, S. (red.) (2006). Gospodarka turystyczna a grupy interesu (2006). Warszawa: Szkoła Główna Handlowa.

WT\&TC, Bloomberg (2019). World, transformed: Megatrends and their implications for travel \& tourism. London, UK: World Travel \& Tourism Council, Bloomberg Media Group.

Yiannakis, A., Gibson, H. (1992). Roles tourists play. Annals of Tourism Research, 19, 287-303. DOI: https://doi. org/10.1016/0160-7383(92)90082-Z

Artykuł wpłyną: 13 kwietnia $2020 \mathrm{r}$. Zaakceptowano do druku: 23 października $2020 \mathrm{r}$. 